\title{
Seasonal variability of the Labrador Current and shelf circulation off Newfoundland
}

\author{
Guoqi Han, ${ }^{1}$ Zhaoshi Lu, ${ }^{2}$ Zeliang Wang, ${ }^{1}$ James Helbig, ${ }^{1}$ Nancy Chen, ${ }^{1}$ \\ and Brad de Young ${ }^{2}$ \\ Received 14 June 2007; revised 19 March 2008; accepted 18 July 2008; published 17 October 2008.
}

[1] Three-dimensional finite element models were established for the Newfoundland and Labrador Shelf to investigate climatological monthly mean wind- and density-driven circulation. The model was forced using wind stresses from the National Center for Environmental Prediction-National Center for Atmospheric Research reanalysis data prescribed at the sea surface, large-scale remote forcing determined from a North Atlantic model, monthly mean temperature and salinity climatology, and $M_{2}$ tide on the open boundary. The model results were examined against various in situ observations (moored current meter, tide gauge, and vessel-mounted acoustic Doppler current profiler data) and satellite drift measurements and discussed together with literature information. The seasonal mean circulation solutions were investigated in terms of relative importance of wind to density forcing for the Labrador Current. The model results indicate significant seasonal and spatial variations, consistent generally with previous study results and in approximate agreement with observations for the major currents. The region is dominated by the equatorward flowing Labrador Current along the shelf edge and along the Labrador and Newfoundland coasts. The Labrador Current is strong in the fall/winter and weak in the spring/summer. The mean transport of the shelf edge Labrador Current is $7.5 \mathrm{~Sv}$ at the Seal Island transect and 5.5 Sv through the Flemish Pass. The seasonal ranges are 4.5 and $5.2 \mathrm{~Sv}$ at the two sections, respectively. Density- and wind-driven components are both important in the inshore Labrador Current. The density-driven component dominates the mean component of the shelf edge Labrador Current while the large-scale wind-forcing contributes significantly to its seasonal variability.

Citation: Han, G., Z. Lu, Z. Wang, J. Helbig, N. Chen, and B. de Young (2008), Seasonal variability of the Labrador Current and shelf circulation off Newfoundland, J. Geophys. Res., 113, C10013, doi:10.1029/2007JC004376.

\section{Introduction}

[2] Ocean circulation and hydrography over the Newfoundland and Labrador Shelf and Slope exhibit prominent seasonal variations, attributable to strong influences of large-scale ocean circulation (the colder and fresher equatorward Labrador Current and the warmer and saltier poleward North Atlantic Current), changes in surface winds and heat flux, and ice formation/melting [Loder et al., 1998]. The influence of the large-scale ocean circulation is of particular relevance to the regional circulation and therefore of great importance in understanding the circulation features and dynamics on the seasonal and interannual scales. In addition to variations of the Labrador Current strength and pathway, meanders and frontal eddies pinched from the North Atlantic Current can generate prominent

\footnotetext{
${ }^{1}$ Biological and Physical Oceanography Section, Fisheries and Oceans Canada, Northwest Atlantic Fisheries Centre, St. John's, Newfoundland, Canada.

${ }^{2}$ Department of Physics and Physical Oceanography, Memorial University of Newfoundland, St. John's, Newfoundland, Canada.

Published in 2008 by the American Geophysical Union.
}

temporal and spatial variability in regional hydrography and circulation, resulting in intensive shelf/deep ocean interactions.

[3] Extensive efforts have been made to understand these profound changes from various perspectives such as the Atlantic Zone Monitoring Program (AZMP) launched by Fisheries and Oceans Canada in late 1990s [Therriault et al., 1998]. The AZMP regularly collect physical, chemical and biological oceanographic data at fixed stations and transects (see Figure 1 for the examples off Newfoundland and Labrador) on the Atlantic Canadian shelves and slopes. For the Newfoundland and Labrador Shelf, a modeling component with an emphasis on physical environments and its impacts on biological and fisheries processes is essential to complement the observational program. In the long run, the modeling component would synthesize in situ and satellite remote sensing data with underlying dynamics to provide observationally based and dynamically consistent water properties and circulation fields.

[4] Quantitative knowledge and dynamical understanding of three-dimensional shelf circulation is not only of physical, but also of biological and environmental importance for this region. Petrie and Anderson [1983] estimated mean 


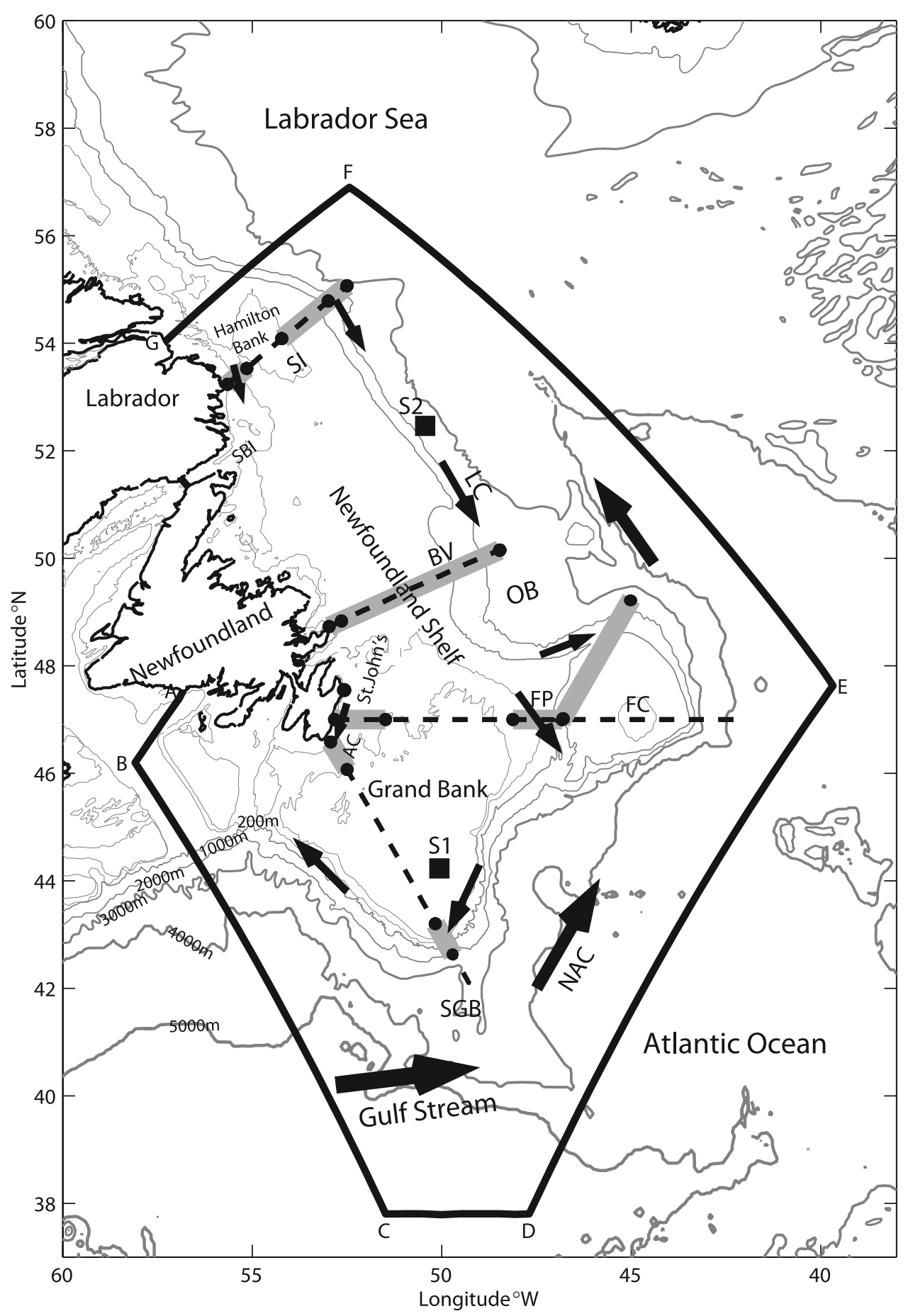

Figure 1. Map showing the Labrador and Newfoundland Shelf and adjacent NW Atlantic Ocean and the model open boundaries (thick solid lines). The isobaths displayed are 100, 200, 1000, 3000, 4000, and $5000 \mathrm{~m}$. The Seal Island (SI), Bonavista (BV), Flemish Cap (FC), and Southeast Grand Bank (SGB) transects are shown as thick dashed lines (from north to south). The filled squares (S1 and S2) are the two sites where the temporal evolution of the model temperature, salinity, and density will be shown in section 4. AC, Avalon Channel; FP, Flemish Pass; LC, Labrador Current; NAC, North Atlantic Current; OB, Orphan Basin; SBI, Strait of Belle Isle. The gray segments with end dots depict the horizontal extent for calculating the volume transport.

flows and transports, and their fluctuations on the Newfoundland Shelf and Slope from various data sources. There have been a number of highly relevant modeling studies focused on the shelf-scale features, e.g., Greenberg and
Petrie's [1988] barotropic model for the mean circulation on the Grand Bank, Hannah et al.'s [1995] linear models for the Grand Bank circulation, Tang et al.'s [1996] diagnostic modeling for the Labrador Shelf, Sheng and Thompson's 


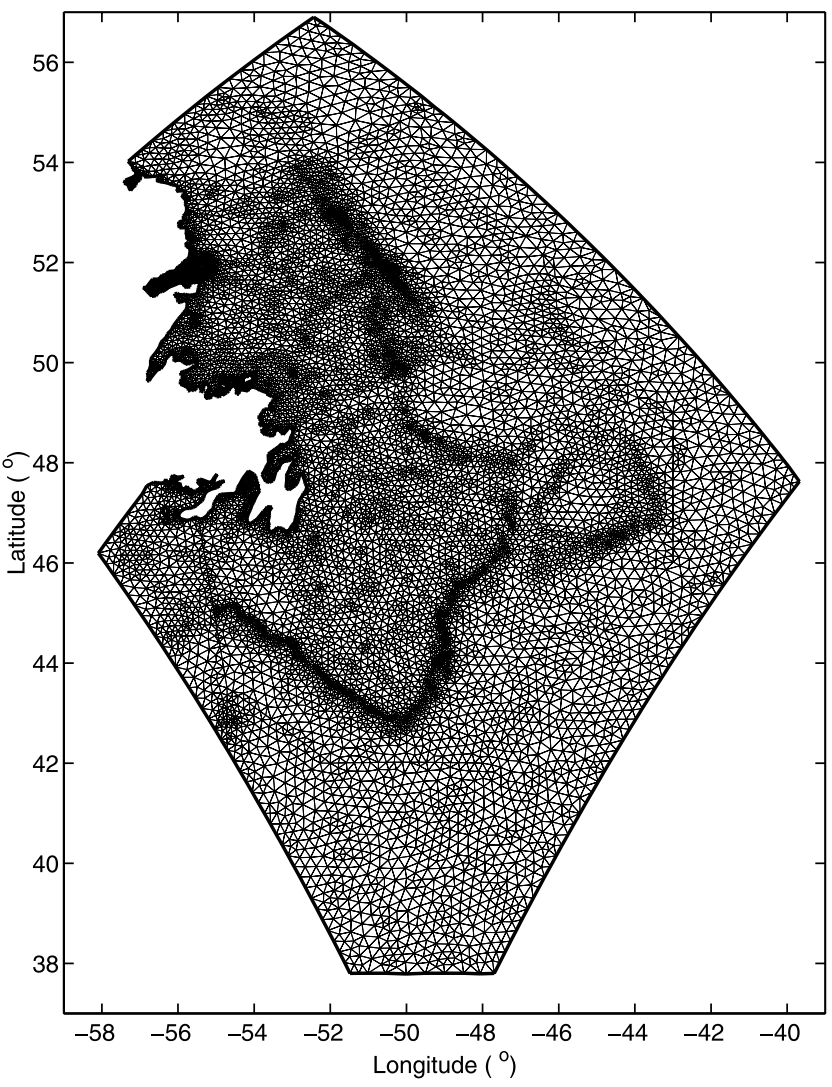

Figure 2. The horizontal finite element grid (slns2) used in the numerical model. The model origin is at $48.5^{\circ} \mathrm{N}$, $49.75^{\circ} \mathrm{W}$.
[1996] diagnostic calculation of summer surface circulation, Han's [2000] simulation of tidal currents and mixing for the Newfoundland Shelf, and Han's [2005] investigation of significance of the barotropic wind-driven circulation off Newfoundland and Labrador and role of regional versus remote forcing in the three branches of the Labrador Current. These model results, in conjunction with in situ observations, indicate significant contributions of both baroclinic and barotropic components to the seasonal mean circulation. However, the Labrador Current ( $\sim 50 \mathrm{~km}$ across the slope) was not well resolved, large-scale boundary forcing is not well accounted for and tide mixing effects are not dynamically included in available baroclinic circulation models.

[5] In this study, a three-dimensional nonlinear finite element model [Lynch et al., 1996] was implemented for the Newfoundland and Labrador Shelf to investigate climatological monthly mean wind- and density-driven circulation. Our major objective is to provide three-dimensional observationally based and dynamically consistent climatological monthly mean circulation fields that compare well with historical observations. The striking advantage of a finite element model is that the unstructured model grid allows a flexible and efficient use of the model resolution [Loder et $a l ., 1997]$. In the present study the model's horizontal grid is designed to well resolve the core signature of the Labrador Current. The model was forced using wind stresses from the National Center for Environmental Prediction (NCEP) National Center for Atmospheric Research (NCAR) reanalysis data prescribed at the sea surface, and large-scale remote forcing determined from a barotropic North Atlantic model [Han, 2005], monthly mean temperature and salinity climatology, and $M_{2}$ tide on the open boundary. Therefore, effects of large-scale boundary forcing and major tidal mixing are better accounted for than the previous models. The present model results reveal significant seasonal varia-
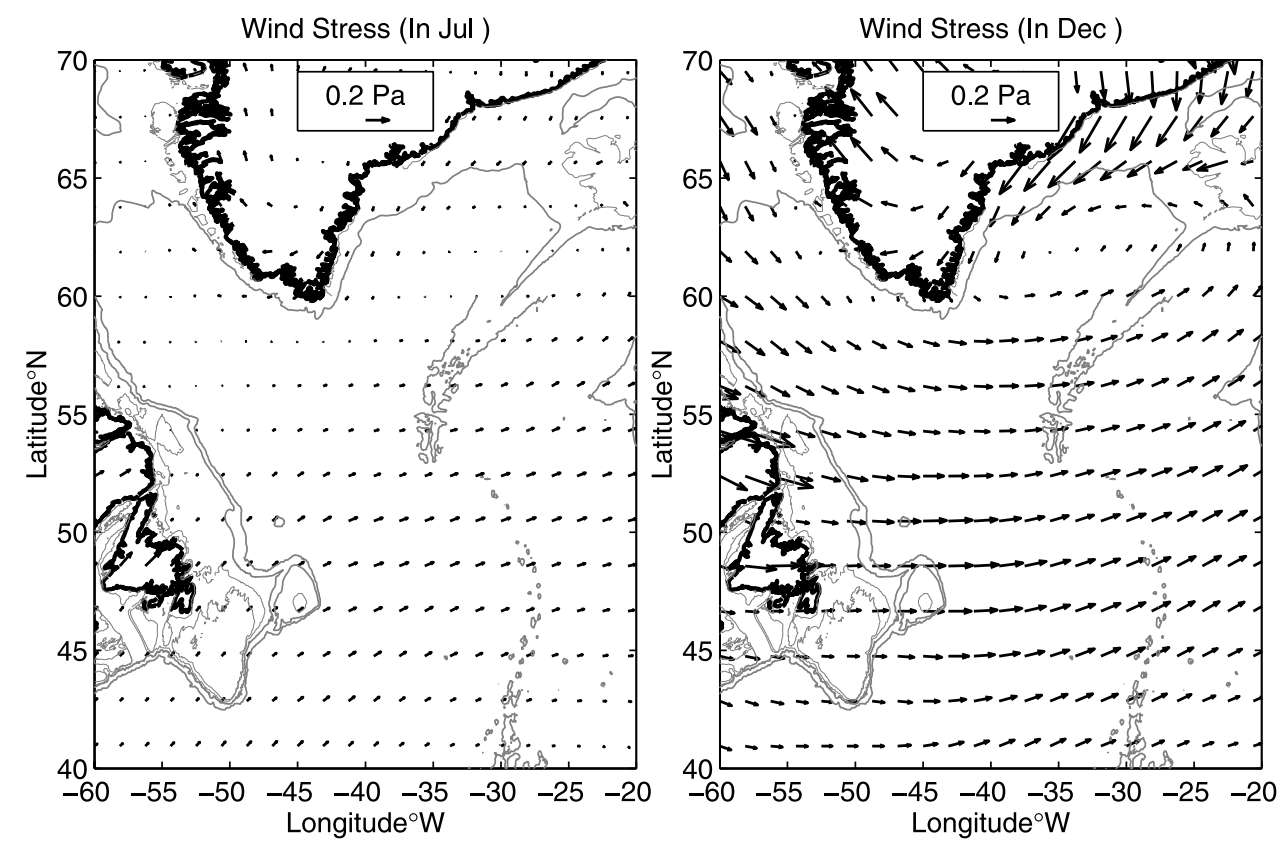

Figure 3. Monthly mean wind stresses calculated from the NCEP/NCAR reanalysis data in (left) July and (right) December. The 100, 200, 1000, and 2000-m isobaths are also shown. 


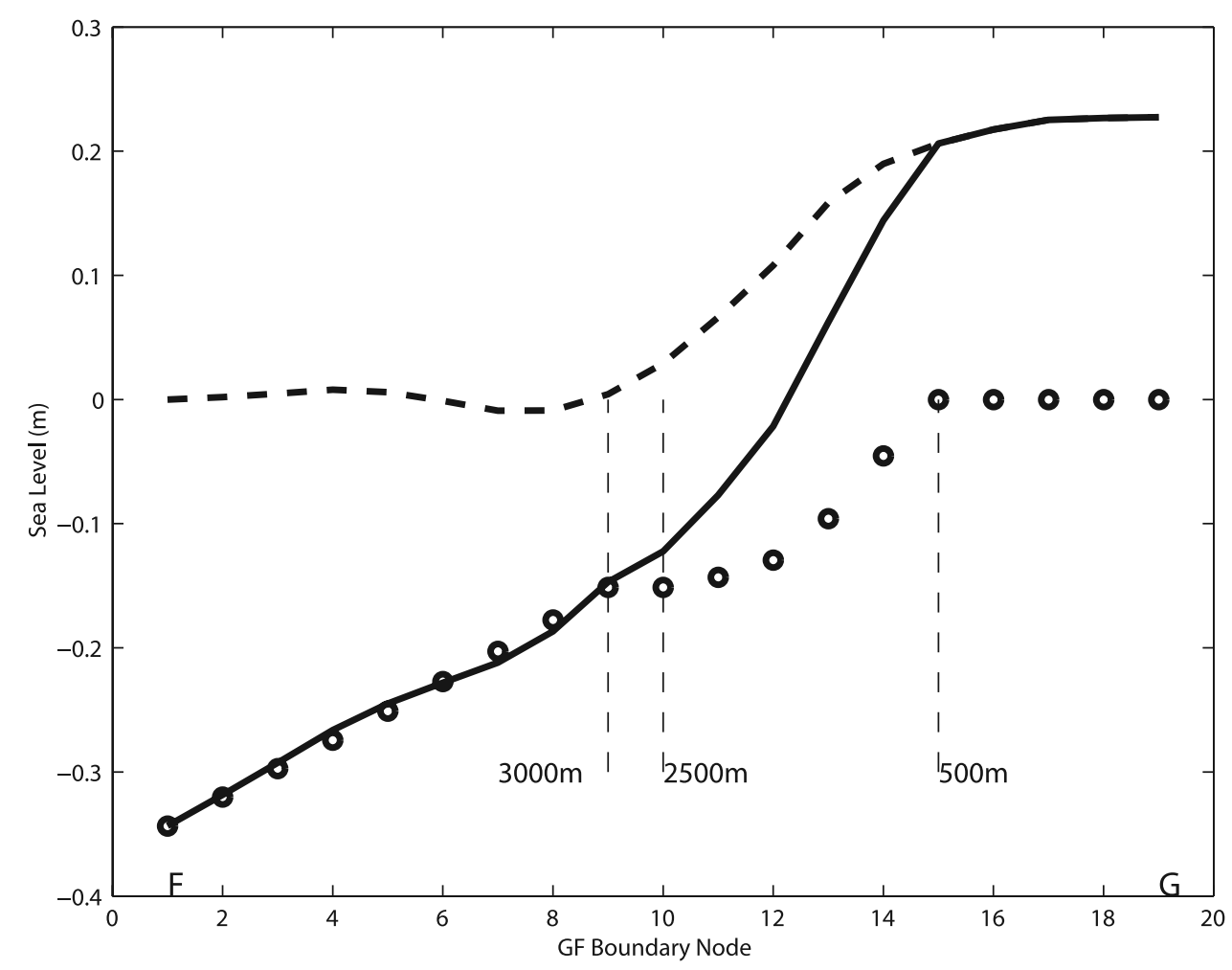

Figure 4. Decomposition of the total sea levels (solid curve) into wind-driven plus steric effect (dashed curve) and the additional inflow component (open circle curve) at the northern boundary GF across the Labrador Shelf and Slope for November. The thin dashed lines depict the locations of the 500, 2500, and 3000-m isobaths. See Figure 1 for the location of the GF open boundary segment.

tions and complex spatial characteristics in wind- and densitydriven circulation fields and agree with various observational data well.

[6] In section 2 we describe the circulation model, initial conditions, boundary conditions and forcing data. The solution procedure is given in section 3. Section 4 analyses the solution procedure, describes model validation metrics and discusses model-observation comparison and evaluation. Section 5 presents climatological mean circulation features. The seasonal variation of currents and transport is examined in section 6. Section 7 discusses dissipation and large-scale wind-driven currents. We conclude with a brief summary in section 8 .

\section{Circulation Models, Initial, and Open Boundary Conditions}

\subsection{Finite Element Model and Mesh}

[7] The finite element model QUODDY4 [Lynch et al., 1996; Han and Loder, 2003] used in this study features 3-D nonlinear primitive equations with Boussinesq and hydrostatic approximations, and a level 2.5 turbulence closure scheme [Mellor and Yamada, 1982; Blumberg et al., 1992]. The vertical eddy viscosity for momentum, and vertical diffusivity for temperature, salinity and turbulent kinetic energy and mixing length scale were given a minimum value of $0.0001 \mathrm{~m}^{2} / \mathrm{s}$. Model solutions with a minimum value of $0.00005 \mathrm{~m}^{2} / \mathrm{s}$ show little difference.
[8] The model's horizontal grid is a linear triangular mesh (Figure 2) of 10927 variably spaced nodes. It covers the southern Labrador Shelf (SLS), the entire Newfoundland Shelf, and adjacent deep oceans. The resolution is high in shallow areas and those with small topographic length scale $(h /|\nabla h|$ where $\mathrm{h}$ is the local water depth), with a typical nodal spacing of $5 \mathrm{~km}$ over the shelf. The vertical grid has 21 variably spaced nodes with minimum spacing of $1 \mathrm{~m}$ near the sea surface and near the seabed, and adjusts to track the movement of the sea surface during the model simulations. The model uses topography for the shelf from the Canadian Hydrographic Service with about 7-km resolution and topography for deep oceans from etopo5.

\subsection{Initial Conditions}

[9] The initial sea surface elevation and 3-D velocity fields for the prognostic models were computed using a frequency domain linear diagnostic model of FUNDY5 [Naimie and Lynch, 1993; Han et al., 1999]. Tidal and monthly mean fields were obtained separately.

Table 1. A Comparison of the Model Mean Transport and Previous Observational Estimates Across the SLS Boundary

\begin{tabular}{ccc}
\hline & Shelf Edge & Entire SLS \\
& and Slope & Boundary (FG) \\
\hline Observational & 11 [Lazier and & $50[$ Han and \\
Estimates & Wright, 1993] & Tang, 1999] \\
Model (Sv) & 13.4 & 45.7 \\
\hline
\end{tabular}



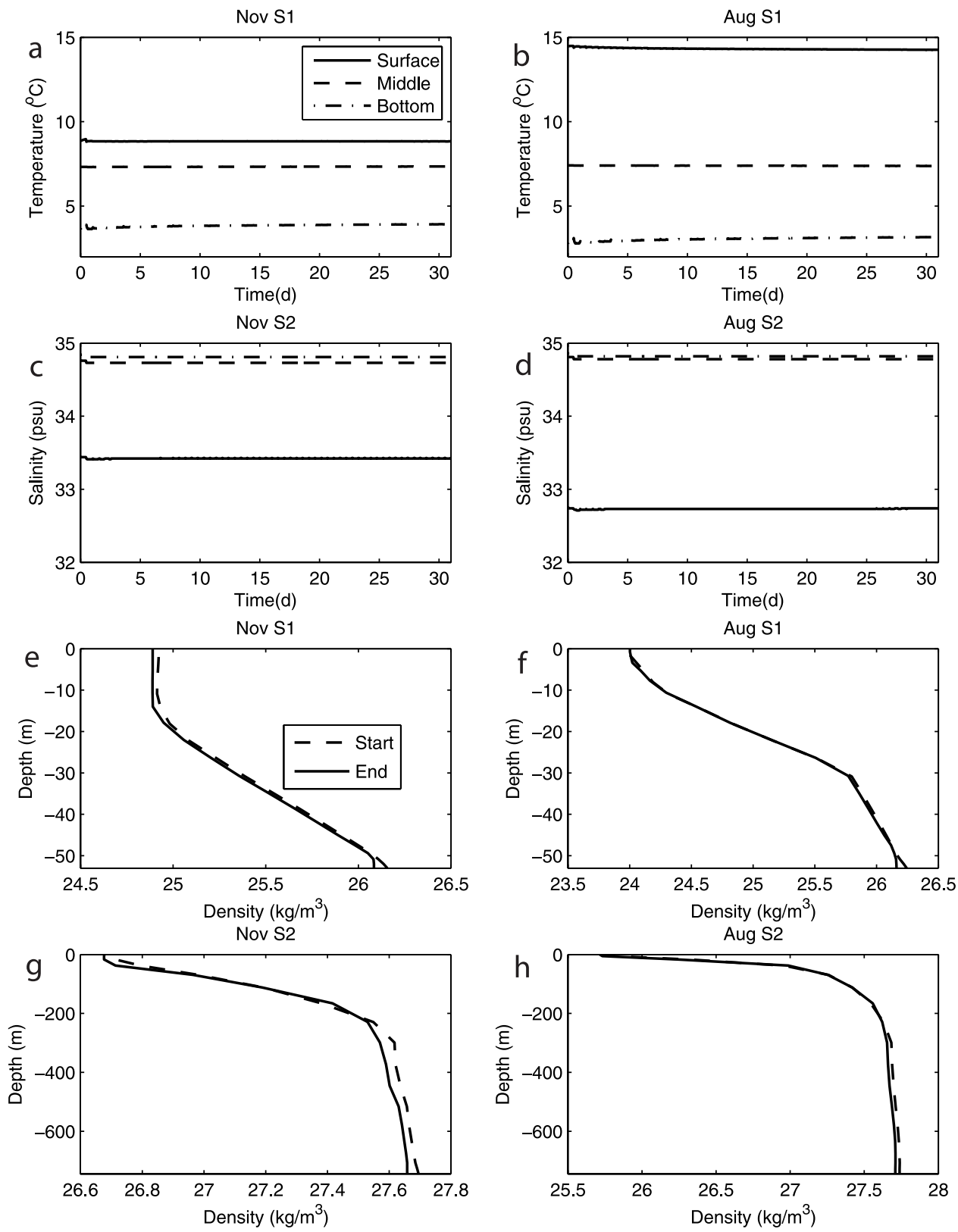

Figure 5. Time series of $(\mathrm{a}-\mathrm{d})$ model temperature and salinity and $(\mathrm{e}-\mathrm{h})$ vertical profiles of density for representative sites and months. Site locations are indicated in Figure 1.

[10] The tidal solution was forced by elevations at the open boundaries, derived from satellite altimetry [Han et al., 1996] and tide gauge data. We include $M_{2}$ tide only in this study, to nominally represent tidal effects [Han et al., 1997]. The $M_{2}$ current is the most significant component in the total tidal current over the Newfoundland Shelf [Han, 2000].

[11] The initial monthly mean solutions were obtained by specifying baroclinic pressure gradients throughout the model domain, spatially variable wind stresses at the sea surface, elevations at the SLS (FG in Figure 1) and offshore (A-F) boundaries, and depth-integrated normal velocities on the Strait of Belle Isle (SBI) boundary. The baroclinic pressure gradients were derived from the density fields calculated from climatological monthly mean temperature and salinity fields [Geshelin et al., 1999]. The monthly mean wind stresses were computed by averaging 6-hourly results on the basis of NCEP-NCAR reanalysis data for the 1990s [Han, 2005]. The monthly mean wind stresses (Figure 3) have seasonal variations in both magnitude and direction, with the winter stress being stronger and directed more cross shelf (offshore) than the stresses during the other seasons.

[12] The SLS and offshore boundary conditions were steric heights derived from the climatological monthly mean density fields to provide zero sea bottom flow normal to the boundary, sea levels from a barotropic North Atlantic model (FUNDY5) driven by the North Atlantic wind stresses 


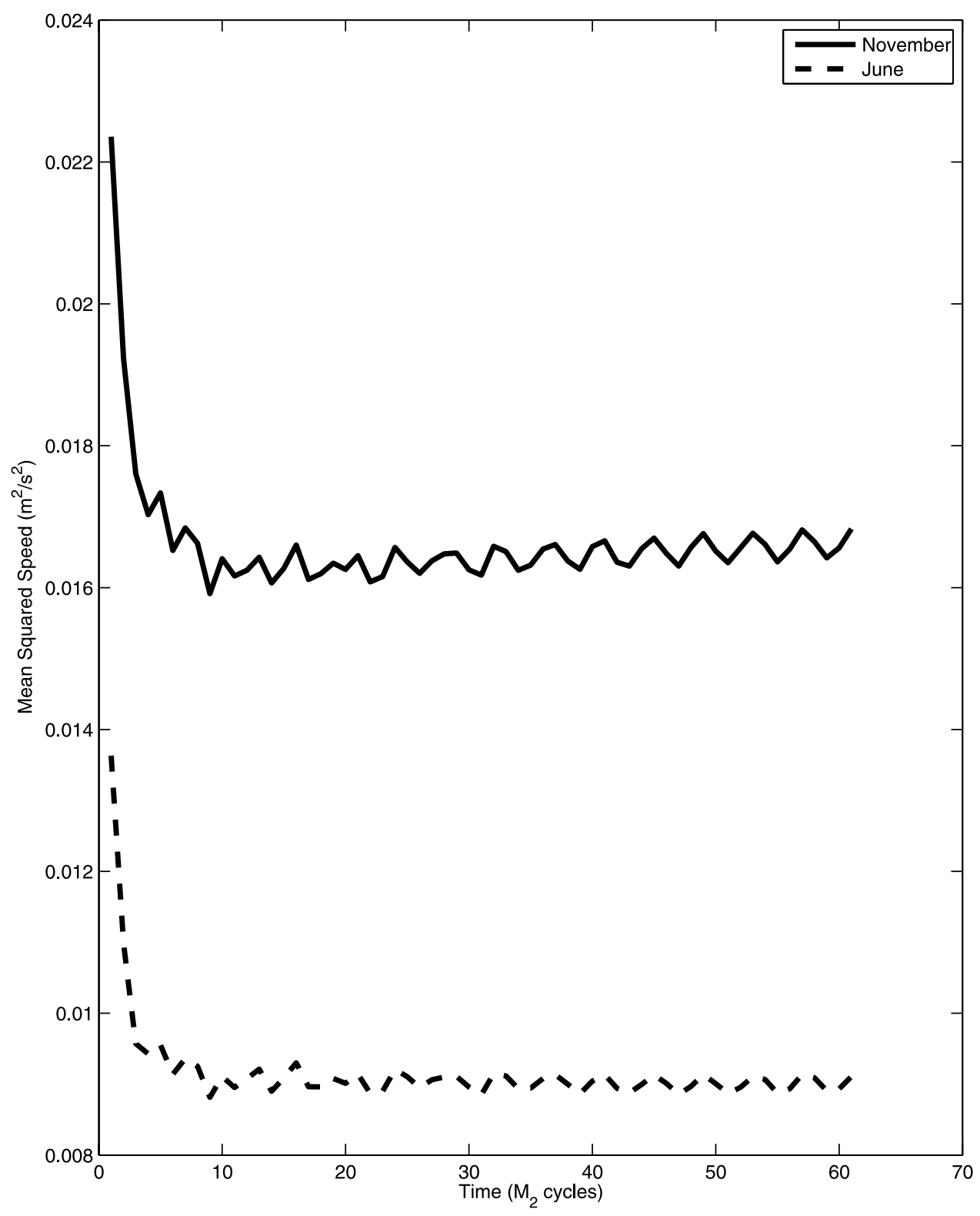

Figure 6. Mean squared speed in November (solid curve) and June (dashed curve), calculated on the basis of the depth and tidal cycle-averaged model velocity.

[Han, 2005], and additional sea levels estimated empirically. Early studies [Lazier and Wright, 1993; Han and Tang, 1999, 2001] have indicated significant alongshelf bottom flows across the SLS boundary (the FG segment in Figure 1), which is unrepresented in the above steric height boundary condition. It suggests also that the geostrophic calculation can significantly underestimate the Labrador Current transport. The geostrophic underestimation of the Labrador Current transport was also indicated by Fratantoni and Pickart [2007]. To overcome this problem, additional inflows were specified at the SLS boundary in an ad hoc way. We linearly distribute additional transports of $7.5 \mathrm{~Sv}$ across the continental slope segment (from the 500-m isobath $140 \mathrm{~km}$ away from the coast to the $2400-\mathrm{m}$ isobath) and $52.5 \mathrm{~Sv}$ across the deep ocean segment from the 3000-m isobath to the location $\mathrm{F}$. The slope value of $7.5 \mathrm{~Sv}$ was chosen on the basis of Lazier and Wright's [1993] estimate of 7.2 Sv, and counted exclusively as a density-driven component in the present study, which may be the bottom intensified flow as a result of the joint effect of the baroclinicity and relief [Lazier and Wright, 1993]. Sea levels (set to zero at $\mathrm{G}$ ) associated with these additional transports were then estimated under the geostrophic assumption, and added on to the steric and wind-driven sea levels as the open boundary condition (Figure 4). As a result, the mean SLS boundary inflow can approximately match previous observational estimates for the shelf edge current (Table 1) and for the Labrador Sea gyre.

[13] To determine where the additional FG inflows will eventually exit the model domain, we ran the FUNDY5 linear model with the specification of geostrophic sea levels associated with the inflows across the FG boundary and under the 
Table 2. Statistics (Means and Standard Deviations) From the Comparison Between Observed and Model Monthly Mean Currents Over the Newfoundland and Labrador Shelf and Slope ${ }^{a}$

\begin{tabular}{|c|c|c|c|c|c|c|c|c|}
\hline \multirow[b]{2}{*}{ Month/Cycle } & \multirow{2}{*}{$\begin{array}{c}\text { Number of } \\
\text { Observations }\end{array}$} & \multicolumn{2}{|c|}{ Average Speed $(\mathrm{cm} / \mathrm{s})$} & \multirow[b]{2}{*}{ SDR } & \multirow[b]{2}{*}{ VDR } & \multirow[b]{2}{*}{$R$} & \multicolumn{2}{|c|}{ Velocity Deviations } \\
\hline & & Observed & Model & & & & $\operatorname{VVD}(\mathrm{cm} / \mathrm{s})$ & $\mathrm{DA}\left({ }^{\circ}\right)$ \\
\hline January & 111 & $11.0 \pm 8.3$ & $14.1 \pm 9.5$ & 0.57 & 0.76 & 0.69 & $9.8 \pm 6.9$ & $32 \pm 49$ \\
\hline February & 99 & $9.7 \pm 6.8$ & $11.2 \pm 8.3$ & 0.44 & 0.57 & 0.76 & $7.3 \pm 5.2$ & $45 \pm 78$ \\
\hline March & 93 & $9.4 \pm 6.6$ & $8.2 \pm 7.2$ & 0.40 & 0.52 & 0.71 & $6.4 \pm 5.4$ & $35 \pm 61$ \\
\hline April & 82 & $8.3 \pm 5.3$ & $9.2 \pm 8.7$ & 0.90 & 1.13 & 0.56 & $7.2 \pm 7.7$ & $36 \pm 61$ \\
\hline May & 92 & $7.6 \pm 4.8$ & $6.6 \pm 6.5$ & 0.58 & 0.70 & 0.62 & $5.5 \pm 5.1$ & $41 \pm 60$ \\
\hline June & 117 & $7.4 \pm 5.0$ & $5.7 \pm 3.3$ & 0.30 & 0.47 & 0.73 & $4.9 \pm 3.5$ & $48 \pm 69$ \\
\hline Cycle $65-71$ & 117 & $7.4 \pm 5.0$ & $5.7 \pm 3.4$ & 0.31 & 0.48 & 0.72 & $5.1 \pm 3.5$ & $50 \pm 65$ \\
\hline Cycle 55-117 & 117 & $7.4 \pm 5.0$ & $5.7 \pm 3.3$ & 0.30 & 0.47 & 0.73 & $5.0 \pm 3.5$ & $49 \pm 66$ \\
\hline July & 169 & $8.3 \pm 6.3$ & $7.1 \pm 5.9$ & 0.35 & 0.56 & 0.68 & $6.1 \pm 4.7$ & $43 \pm 59$ \\
\hline August & 184 & $8.6 \pm 6.0$ & $7.6 \pm 6.3$ & 0.42 & 0.71 & 0.61 & $7.0 \pm 5.5$ & $47 \pm 61$ \\
\hline September & 169 & $9.2 \pm 6.4$ & $8.4 \pm 6.1$ & 0.30 & 0.48 & 0.73 & $6.2 \pm 4.7$ & $44 \pm 66$ \\
\hline Diagnostic & 169 & $9.2 \pm 6.4$ & $8.8 \pm 6.7$ & 0.41 & 0.63 & 0.67 & $7.0 \pm 5.5$ & $47 \pm 66$ \\
\hline October & 127 & $9.6 \pm 7.1$ & $9.2 \pm 6.6$ & 0.28 & 0.51 & 0.70 & $7.1 \pm 4.7$ & $52 \pm 76$ \\
\hline November & 93 & $12.0 \pm 8.7$ & $11.3 \pm 8.1$ & 0.28 & 0.35 & 0.80 & $7.3 \pm 4.8$ & $28 \pm 44$ \\
\hline Cycle $65-71$ & 93 & $12.0 \pm 8.7$ & $11.3 \pm 8.2$ & 0.29 & 0.35 & 0.79 & $7.3 \pm 4.9$ & $30 \pm 49$ \\
\hline Cycle 55-117 & 93 & $12.0 \pm 8.7$ & $11.2 \pm 8.2$ & 0.29 & 0.36 & 0.79 & $7.3 \pm 5.0$ & $31 \pm 49$ \\
\hline December & 114 & $12.6 \pm 9.3$ & $13.2 \pm 9.2$ & 0.35 & 0.49 & 0.75 & $9.1 \pm 6.2$ & $45 \pm 68$ \\
\hline
\end{tabular}

${ }^{a} \mathrm{SDR}$ and VDR are defined by equations (2) and (3). $R$ is the correlation coefficient calculated for both eastward and northward components. The vector velocity difference (VVD) is the magnitude of the difference vector between the observed and modeled velocities. The difference angle (DA) is the magnitude of their difference in direction.

geostrophic condition on all other open boundaries. The computed sea levels on the ABCDEF open boundary (see Figure 1) were then added onto steric and wind-driven sea levels. As expected, the additional FG inflows essentially follow $f / h$ ( $f$ is the Coriolis parameter) contour with the influences of frictional effects. The shelf edge and upper slope inflow $(7.5 \mathrm{~Sv})$ mainly continues along the shelf edge and continental slope; while the deep sea inflow exits on the EF segment, and has little effect on the shelf and upper slope flows of interest. The steric and wind-driven sea level on the northern boundary can approximately account for observed seasonal variation, so the additional inflow is assumed to be time independent. As a result, the additional inflow will not affect the model seasonal variability.

[14] The SBI boundary conditions were the depthintegrated velocities associated with zero normal bottom flow, also derived from steric computations on the climatological density fields. A geostrophic balance was enforced at the open boundary AB (see Figure 1).

\subsection{Boundary Conditions for Prognostic Solutions}

[15] For prognostic refinement solutions, temperature and salinity at the open boundaries were fixed to be the climatological values interpolated from Geshelin et al.'s [1999] fields. Zero normal gradients of temperature and salinity were enforced at the lateral land boundaries. Surface temperature was restored toward an evolving mean field calculated from the immediately preceding $M_{2}$ cycle on a timescale of $12.42 \mathrm{~h}$ (one $M_{2}$ cycle), and no-flux conditions were used for salinity and turbulence quantities at the sea surface. At the sea bottom, the turbulent mixing length scale was set to $0.4 \mathrm{~m}$ and the turbulent kinetic energy was specified on the basis of the bottom friction velocity which is the square root of the bottom kinematic stress.

[16] Elevations were specified along the open boundaries, derived from the appropriate diagnostic solutions described in section 2.2. Zero normal velocity was specified at the land boundaries, and the monthly mean wind stresses (e.g., Figure 3) were again specified.

[17] It is worthwhile to point out although sea ice formation, advection and melting are not explicitly considered some of their effects on the circulation are implicitly included through their contribution to the observed density fields. Nevertheless, sea ice dynamics may have significant impact on wind stress, which in turn would affect mixing and momentum transfer that further modify regional circulation at different timescales.

\section{Solution Procedure}

[18] The model was integrated forward in time from the initial states using the boundary conditions described in the preceding section. We chose a time step of $43.66 \mathrm{~s}$. As a result there were 1024 time steps for each $M_{2}$ tidal cycle simulation. A novel feature in this study was that model solutions were obtained with the temperature and salinity fields at subsurface interior nodes restored toward their initial values (for the first $M_{2}$ cycle) and toward evolving $M_{2}$ cycle mean values (for the second and subsequent $M_{2}$ cycles) (the same as for the surface temperature field). For example, the nudging scheme temperature $T$ is

$$
T^{a}=\gamma \bar{T}+(1-\gamma) T^{n},
$$

where $T^{a}$ is the analysis temperature after the nudging at the nth time step, $\bar{T}$ is either the temperature climatology for the first $M_{2}$ cycle $(n \leq 1024)$ or the average of the model output during the immediately preceding $M_{2}$ cycle, $T^{n}$ is the model calculated temperature at the $n$th time step, and $\gamma$ varies linearly from 1 at the start of each $M_{2}$ cycle and to 0 at the end of each $M_{2}$ cycle.

[19] As noted in the Introduction, one of our objectives is to obtain realistic and dynamically self-consistent current fields under the tidal-scale adjustment. We have thus run the prognostic model, initialized with the observed climatological hydrographic states and associated velocity and 


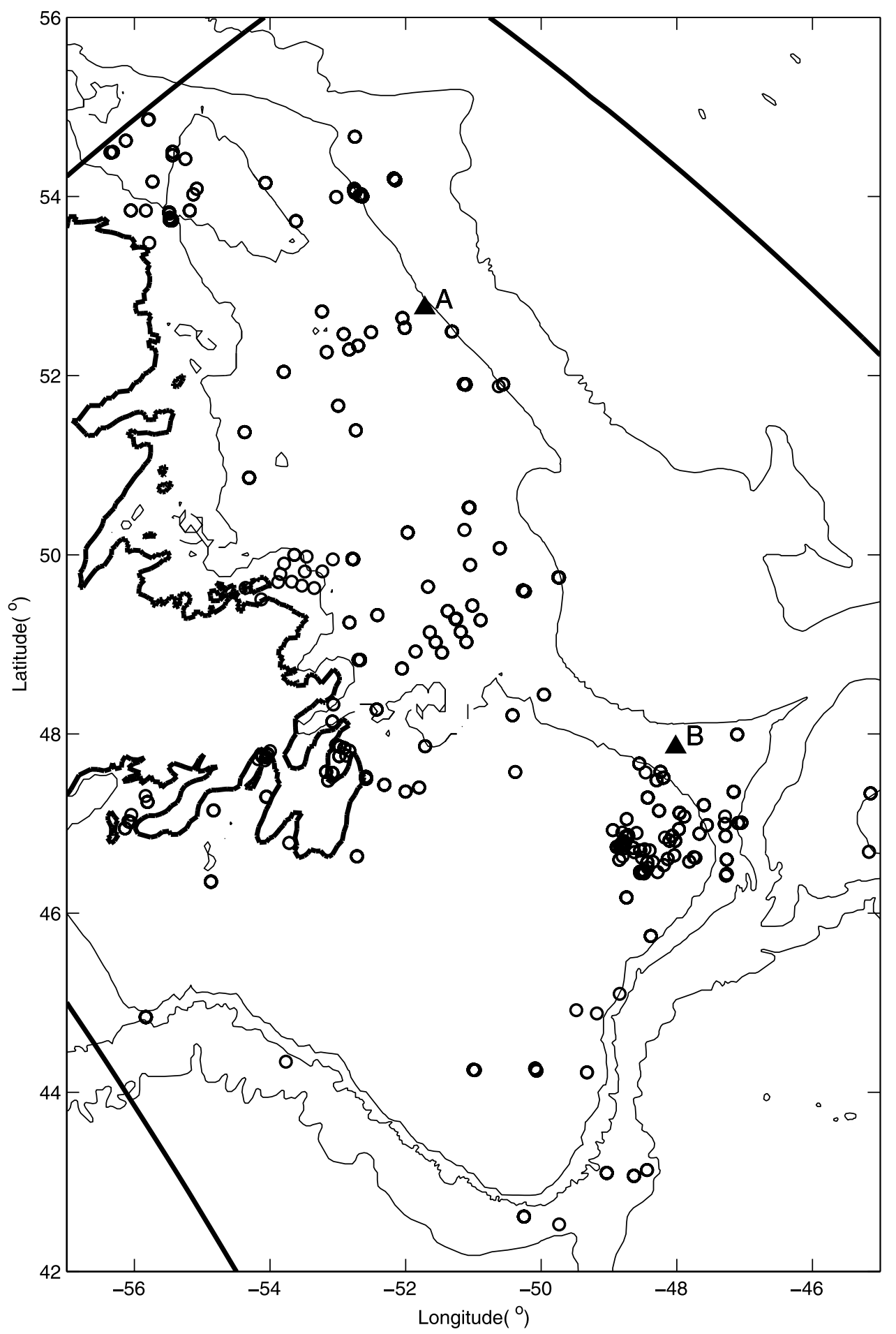

Figure 7. Sites of historical moored measurements for all months used in the model evaluation. The 200, 1000, and 3000-m isobaths are also shown. The two solid triangles (sites A and B) indicate the locations where the model and observational current profiles are compared in Figure 9.

elevation fields, with a strategy of sufficient refinement through the restoring approach to reach a quasi-steady dynamic equilibrium among the prognostic variables (temperature, salinity, density, elevation, velocity and turbulence quantities). The case with subsurface restoration, which is a common practice in numerical modeling of ocean circulation [e.g., Foreman et al., 2000], was included in order to prevent the (nonlinear) prognostic model solution from drifting significantly away from the specified observationally based state (the linear diagnostic solution). The new nudging approach, with the prognostic variables constrained at the open boundaries, allowed the interior fields to reach a full dynamic equilibrium under the tidal-scale adjustment.

[20] The model was run for $61 M_{2}$ tidal cycles (about 30 days) until an overall dynamical equilibrium is established. The model output for cycles 55-61 was used in 

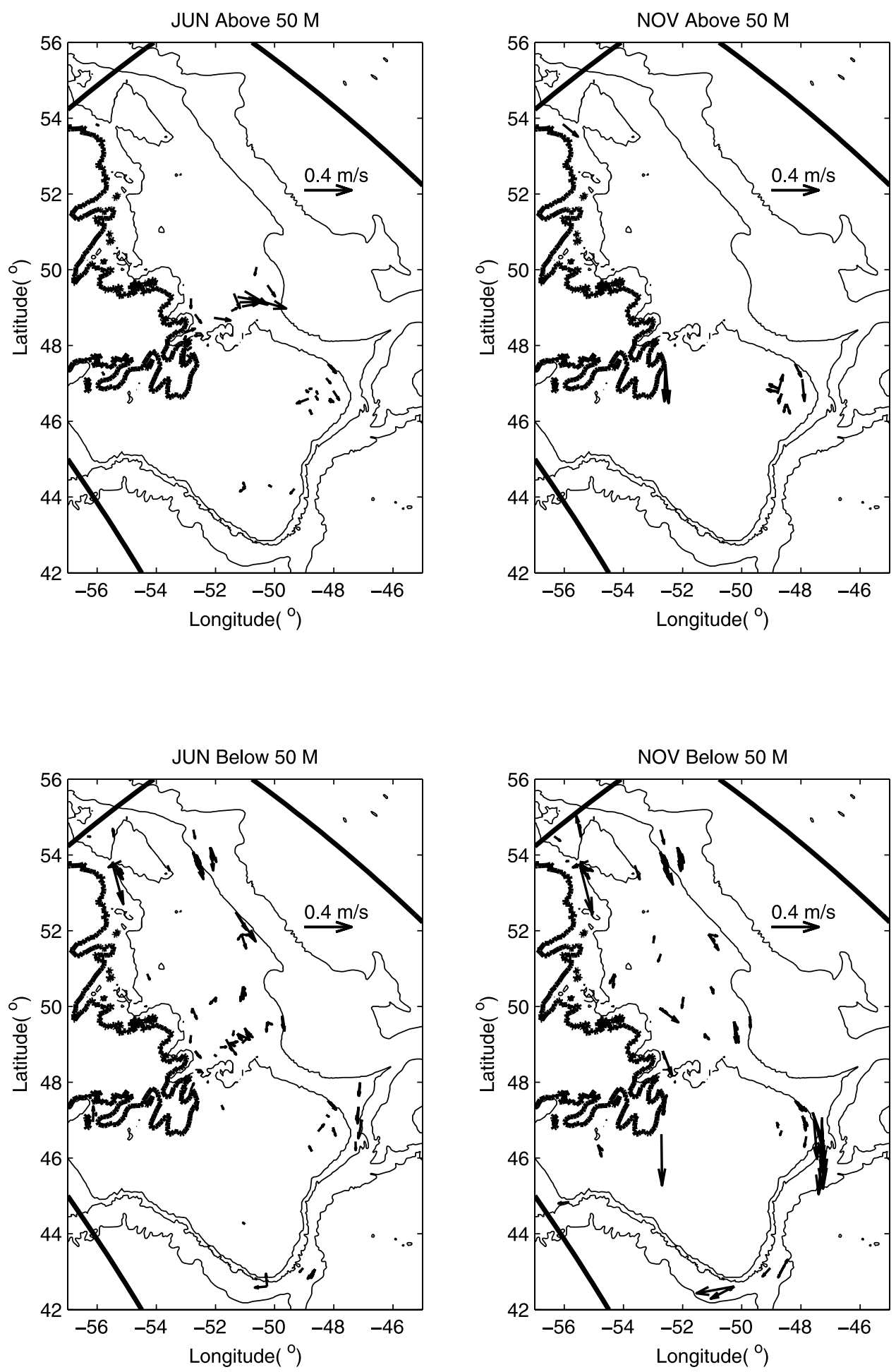

Figure 8. Currents from historical moored measurements in (left) June and (right) November (top) above and (bottom) below the 50-m depth. The 200, 1000, and 3000-m isobaths are also shown. 

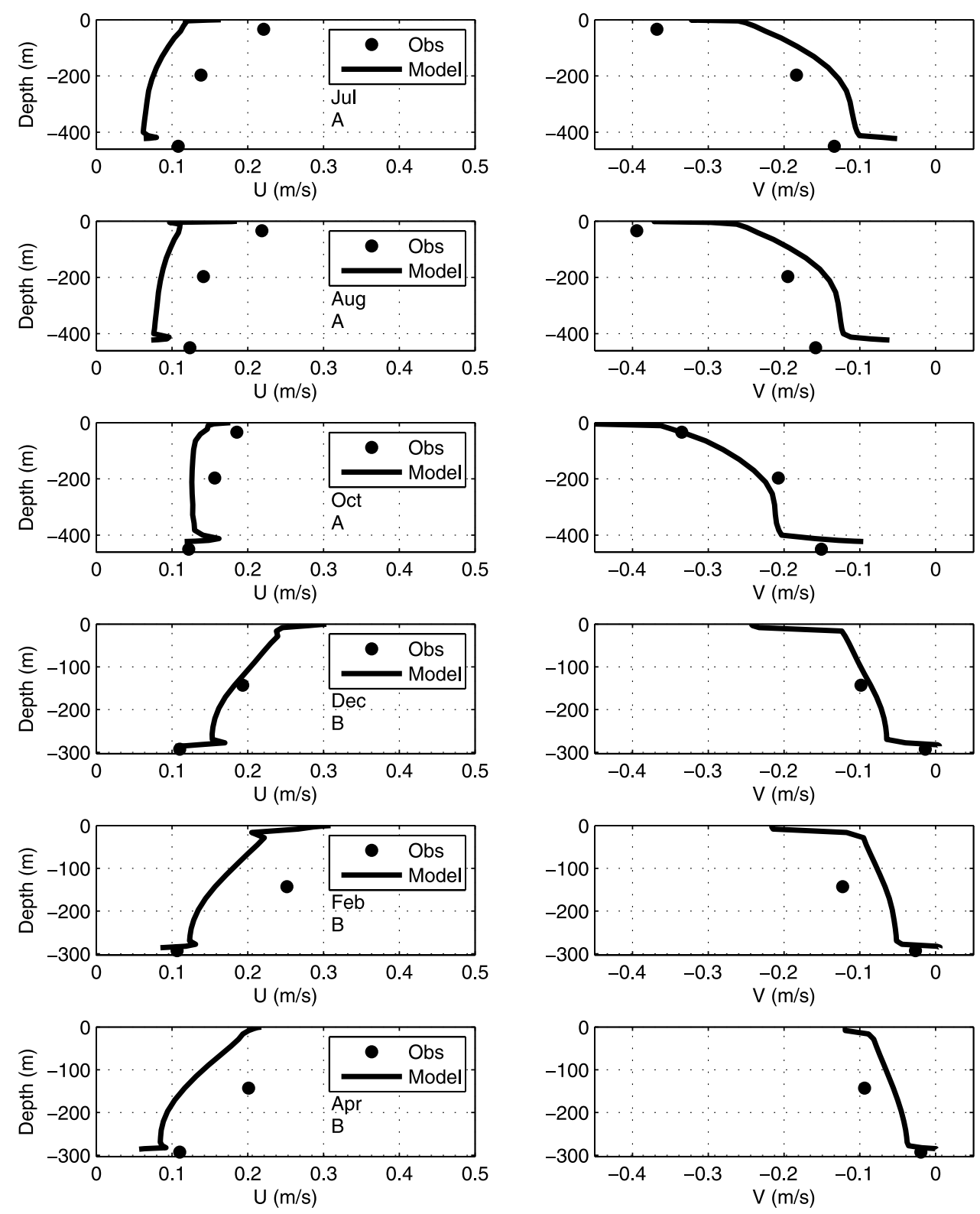

Figure 9. Comparison of selected model current profiles and moored measurements. $U$ and $V$ are the eastward and northward components, respectively. See Figure 5 for the locations of sites A and B.

harmonic analyses to retrieve the seasonal mean components, while effectively removing the $M_{2}$ tidal variation and potential inertial oscillation. See section 4.2 for analysis and discussion.

\section{Model Validation}

\subsection{Calculation of Model-Observation Comparison Statistics}

[21] To evaluate the model solutions qualitatively and quantitatively, we compare the model currents with moored measurements. Model horizontal velocities were linearly interpolated to instrument depths for each site. A number of overall statistics were calculated for all observational sites for each monthly mean flow field, including the means and standard deviations for each of the observed current speed, the model current speed, the magnitude of the vector velocity difference between the observed and model velocities, and the difference angle between the observed and model velocities, and the model-observation correlation coefficient. Three primary goodness-of-fit indices were used. One is a velocity difference ratio (VDR) defined as the ratio of the sum of the squared magnitudes of the vector velocity differences to the sum of the squared magnitudes of the observed velocities, that is,

$$
\mathrm{VDR}=\sum\left|V_{m}-V_{o}\right|^{2} / \sum\left|V_{o}\right|^{2},
$$

where $V_{m}$ is the horizontal model velocity and $V_{o}$ is the horizontal observational velocity. Lower VDR values indicate better agreement, with VDR $=0$ being the exact agreement. 


\section{Climatological Mean Surface Currents}

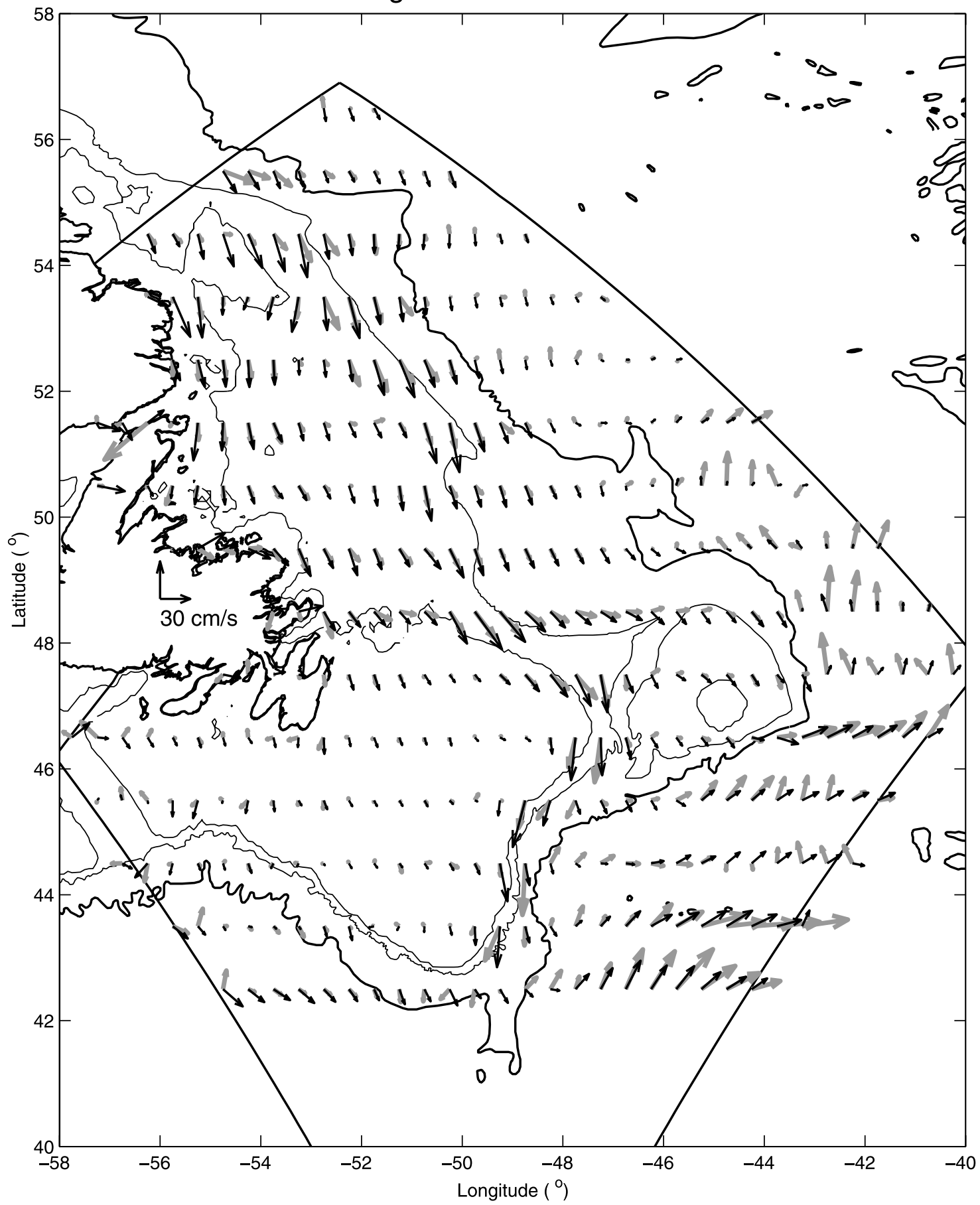

Figure 10. Comparison of model surface (thin black arrows) currents with currents estimated from satellite drifter data (thick gray arrows). The 200, 1000, and 3000-m isobaths are also depicted.

[22] Another is a speed difference ratio (SDR) defined as the ratio of the sum of the squared speed differences to the sum of the squared magnitudes of the observed velocities, that is,

$$
\mathrm{SDR}=\sum\left(\left|V_{m}\right|-\left|V_{o}\right|\right)^{2} / \sum\left|V_{o}\right|^{2}
$$

The other is the correlation coefficient $(R)$ between the model and observational velocity components.

\subsection{Analysis of the Solution Procedure}

[23] The time series of the model temperature, salinity, and density at selected nodes show that their changes within each tidal cycle and between the tidal cycles are small (Figure 5). But the advantage of the present nudging scheme over the diagnostic approach is to allow some adjustment of these quantities under model dynamics, which can eliminate any unphysical features (such as unstable stratification) in 
(a) ADCP Data (spring)

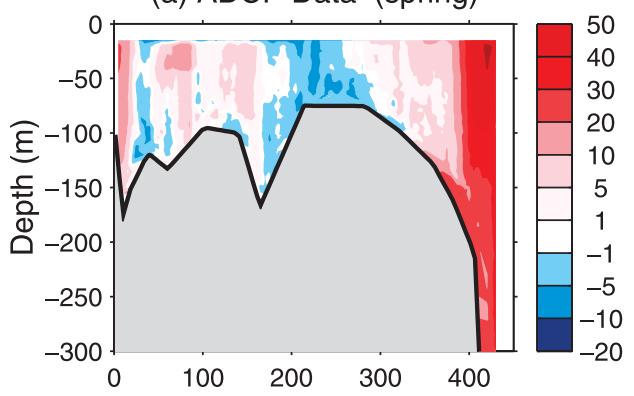

(c) ADCP Data (summer)

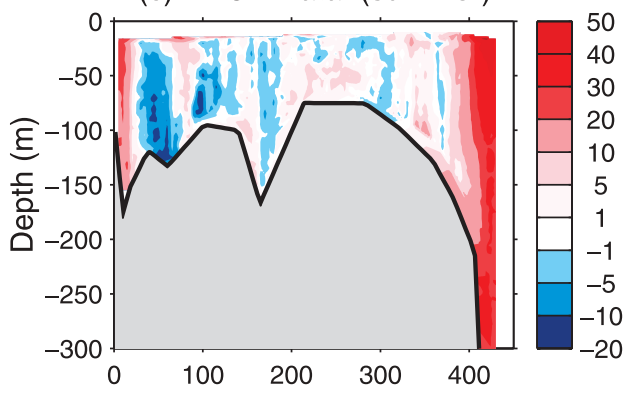

(e) ADCP Data (fall)

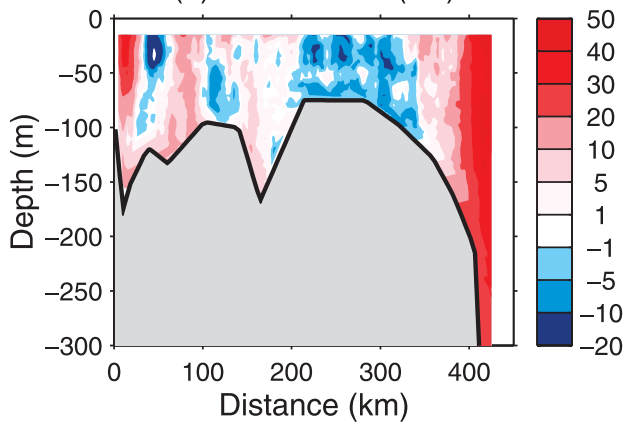

(b) Model (spring)

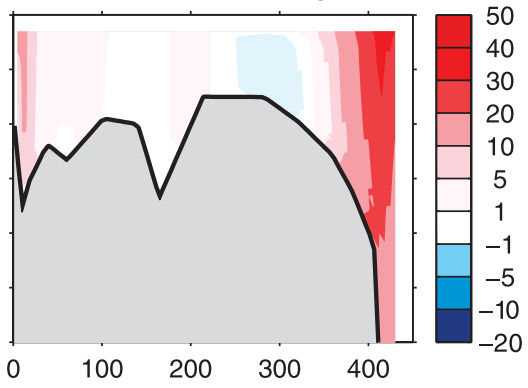

(d) Model (summer)

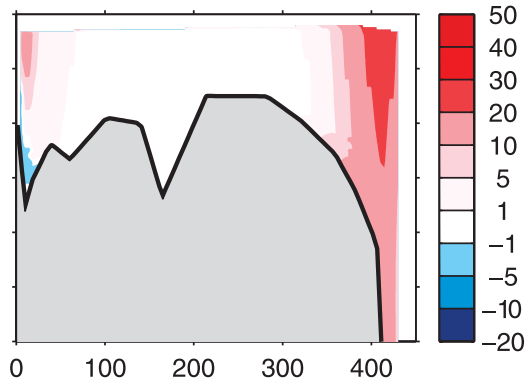

(f) Model (fall)

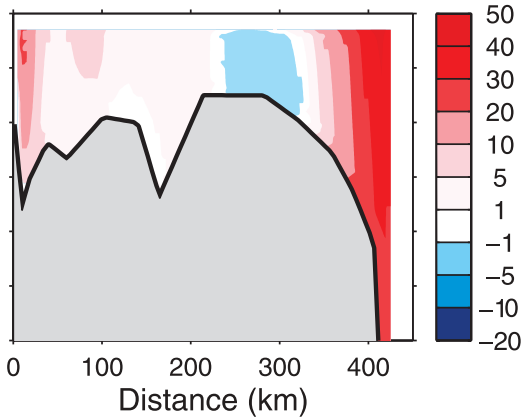

Figure 11. Comparison of the model currents with vessel-mounted ADCP data at the Flemish Cap transect. ( $\mathrm{a}-\mathrm{f}$ ) Only the normal component (in $\mathrm{cm} / \mathrm{s}$, positive southward) is shown. In scatter diagrams between the model and ADCP currents in (g) spring and (h) fall, open circles and crosses are for the northward and eastward components, respectively.

the initial climatology and establish the bottom and surface boundary layers better.

[24] The mean squared speed for November and June (Figure 6) clearly shows a rapid evolution during the first 10 tidal cycles. After 40 cycles it exhibits a weak oscillation at a period of about four $M_{2}$ cycles, the synodical period between the $M_{2}$ tide and the inertial oscillation at the central latitude of the region $\left(47^{\circ} \mathrm{N}\right)$. As indicated in section 3 , the model output for cycles 55-61 (longer than the synodical period between the $M_{2}$ and inertial period) was chosen to retrieve the seasonal mean components. The results from cycle 65-71 and from cycle 55-117 were examined, showing little differences, as presented for November and June (Table 2).

\subsection{Evaluation Against Moored Current Meter Data}

[25] The moored current meter data were extracted from a database maintained at the Bedford Institute of Oceanography [Gregory and Bussard, 1996]. Monthly mean currents were derived from this database, for months with a minimum of 20 days of data. Typically, each mooring site has observations from one to three depths (positions in the vertical) in 1 or 2 years. Observations are made mostly along the shelf edge Labrador Current, near Hamilton Bank, Belle Isle Bank, Funk Island Bank and the northeast Grand Bank (Figure 7). The observed data clearly indicate dominant equatorward flows (Figure 8) and vigorous cross-shelf exchanges. There is also a strong seasonal contrast in the flows, for example, larger in fall/winter than spring/summer (Table 2 and Figure 8). The shelf edge and inshore Labrador Current are clearly evident. The monthly mean shelf edge Labrador Current can reach $40 \mathrm{~cm} / \mathrm{s}$ through the Flemish Pass.

[26] The model currents are evaluated against moored current measurements using the method described in section 4.1. The statistics for each month are summarized in Table 2. The results indicate overall good qualitative and fair quantitative agreement. The agreement is usually better when the current is strong, for example, in fall. All three primary indices indicate the best agreement in November and the poorest in April. An examination also indicates that these indices can change spatially, with larger $R$ and smaller SDR/VDR (better agreement) in the shelf edge zone where 

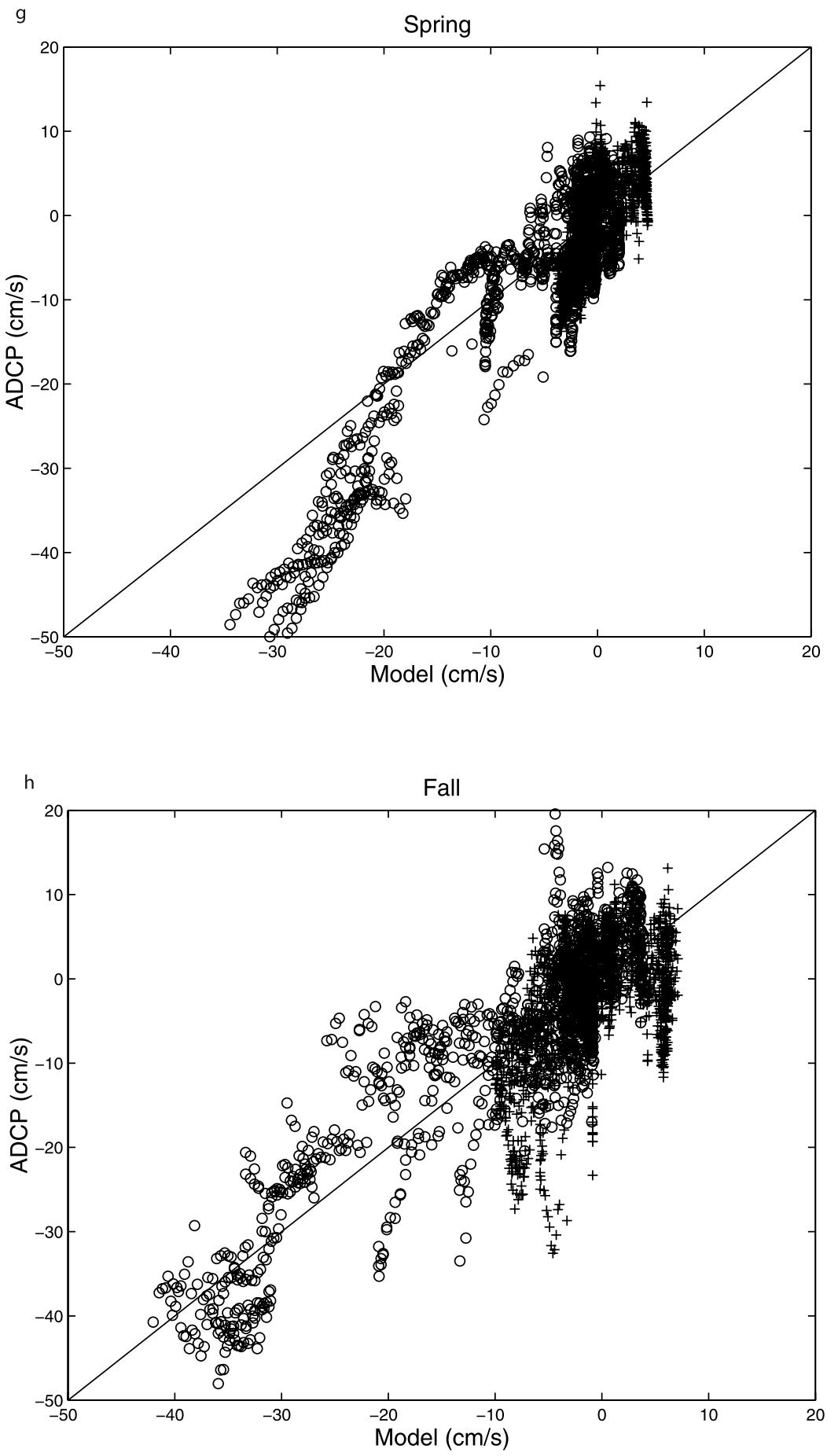

Figure 11. (continued)

the dominant Labrador Current is located. As expected, the velocity difference ratio is usually bigger than the speed difference ratio, since the former takes the current direction discrepancy into account. A similar evaluation of the diagnostic solution indicates that the present semidiagnostic method has better model-observation agreement for summer months (Table 2). The effect on the model-observation statistics is minor for the other months.

[27] A comparison of model current profiles with moored measurements is shown for selected sites (Figure 9). The model results show overall agreement with observations for the shelf edge Labrador Current. The vertical gradient of the horizontal current is well captured in the model results. Although the mean barotropic component (bottom current) may be sensitive to additional barotropic inflows specified across the shelf edge and upper slope on the northern boundary, the vertical gradient is essentially determined by the internal density structure. The comparison also indicates that the barotropic (bottom) current in the shelf 


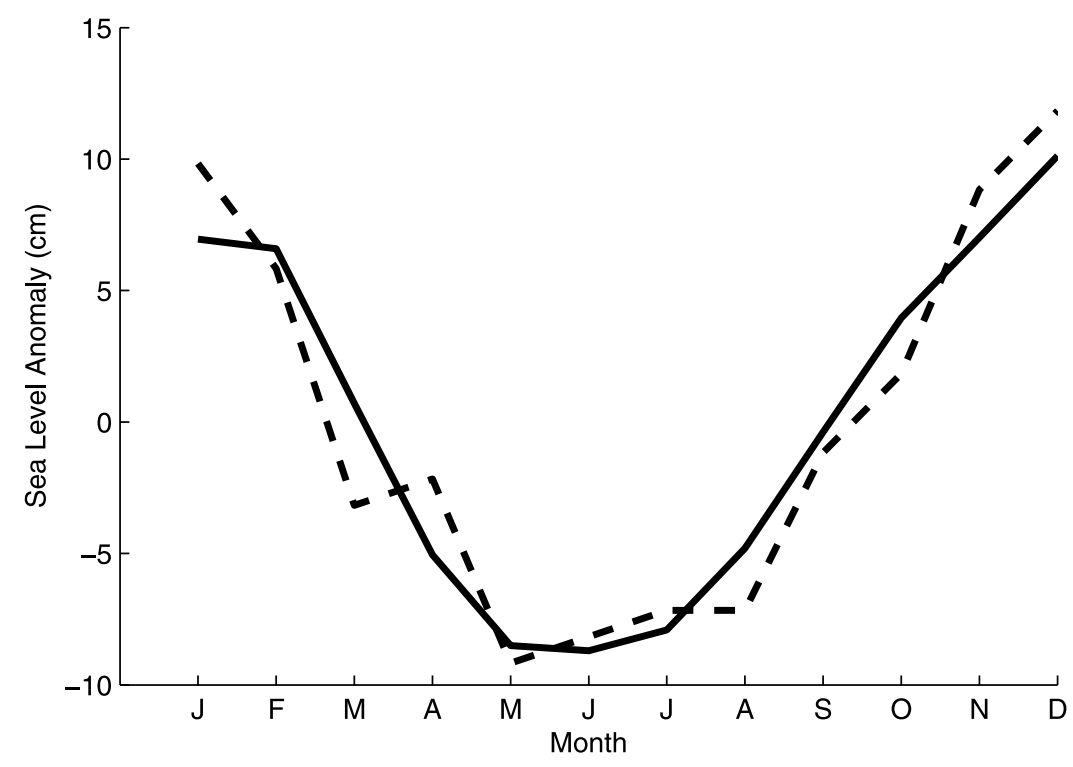

Figure 12. Comparison of the model sea level anomaly (solid curve) with tide gauge data (dashed curve) at St. John's.

edge Labrador Current over the upper continental slope is well represented in the model solution.

\subsection{Comparison With Satellite Drifter Data}

[28] The model surface flows are compared with currents estimated from satellite tracked drifter trajectories (Figure 10). All drifting buoy data in the Marine Environmental Data Service database for the period of 1980-2005 in the Northern Northwest Atlantic $\left(40-55^{\circ} \mathrm{W}, 42-50^{\circ} \mathrm{N}\right.$, and $\left.40-65^{\circ} \mathrm{W}, 50-65^{\circ} \mathrm{N}\right)$ were analyzed. $B$ splines were fit to the north-south and east-west coordinates of each buoy track to form evenly spaced, 3-h time series of position and velocity. The resultant series then were filtered with a seventh-order low-pass Butterworth filter to exclude variability at timescales less $10 \mathrm{~h}$. Extensive numerical simulations with the velocity extraction algorithm indicated that the resultant speed estimates had mean errors less than $10 \mathrm{~cm} / \mathrm{s}$, i.e., similar to those induced by the buoy's inherent inability to follow surface currents exactly. The satellite data were binned in $0.5^{\circ}$ (longitude) by $1^{\circ}$ (latitude) resolution.

[29] We can see good qualitative agreement of the model surface currents with satellite drifter observations. Both model and drifter results show dominant equatorward flows with two strong currents along the shelf edge (the shelf edge Labrador Current) and along the coast (the inshore Labrador Current). The offshore flow over the northeastern Newfoundland Shelf is evident in the model solution and drifter estimates. Quantitatively, the RMS current magnitude is 18 $\mathrm{cm} / \mathrm{s}$ from the model and $14 \mathrm{~cm} / \mathrm{s}$ from the drifter data, with RMS speed and direction differences of $7.5 \mathrm{~cm} / \mathrm{s}$ and $52^{\circ}$ in the shelf and slope region (inshore of the 3000-m isobath; a total of 164 comparisons). If we assume the errors in the model and observations are independent, the error can be estimated as RMS differences divided by 1.414 . Hence the estimated errors are $5.3 \mathrm{~cm} / \mathrm{s}$ and $37^{\circ}$, respectively. The velocity difference ratio (VDR) is calculated to be 0.52 , with a vector velocity difference of $10 \mathrm{~cm} / \mathrm{s}$ and a difference angle of $34 \pm 39^{\circ}$. The correlation coefficient between the model and drifter currents (including both eastward and northward components) is 0.83 .

\subsection{Assessment Against Acoustic Doppler Current Profiler Data}

[30] Vessel mounted acoustic Doppler current profiler (ADCP) current data at the Flemish Cap transect [Senciall et al., 2006] were detided using Han's [2000] tide model. The ADCP data were collected with the bottom tracking technology. There are no data in Flemish Pass for depths greater than $300 \mathrm{~m}$. There are 11 sections in April, 9 sections in July and 3 sections in November for the period from 1992 to 2004. Five leading tidal constituents $\left(M_{2}, S_{2}\right.$, $N_{2}, K_{1}$, and $O_{1}$ ) were included for detiding. The detided ADCP currents are averaged by season to generate April, July, and November means.

[31] There is good qualitative agreement between the present model and the ADCP measurements, in terms of the spatial distribution pattern and the current strength for the dominant southward current (Figure 11). The model southward shelf edge flow agrees well with the ADCP current in fall, but is substantially lower in both April and July (Figure 11). The discrepancy may be in part due to the model inadequacy and the ADCP measurement error, but the ADCP data availability in relation to the significant year-to-year variability may be a more dominant factor. In November, the mean speed is 15.2 and $17.0 \mathrm{~cm} / \mathrm{s}$ from model and ADCP, with an RMS difference of $9.2 \mathrm{~cm} / \mathrm{s}$. The velocity difference ratio is 0.29 . In April, the mean speed is 10.9 and $16.0 \mathrm{~cm} / \mathrm{s}$, with an RMS difference of $7.5 \mathrm{~cm} / \mathrm{s}$. In summer the model and ADCP speed is 9.0 and $13.1 \mathrm{~cm} / \mathrm{s}$, with an RMS difference of $8.5 \mathrm{~cm} / \mathrm{s}$. The correlation coefficient is $0.90,0.73$, and 0.81 for the spring, summer and fall, respectively.

[32] The model volume transport was compared with that based on the ADCP data for the inshore Labrador Current (100 km from the coast). The ADCP-based transport is 0.40 


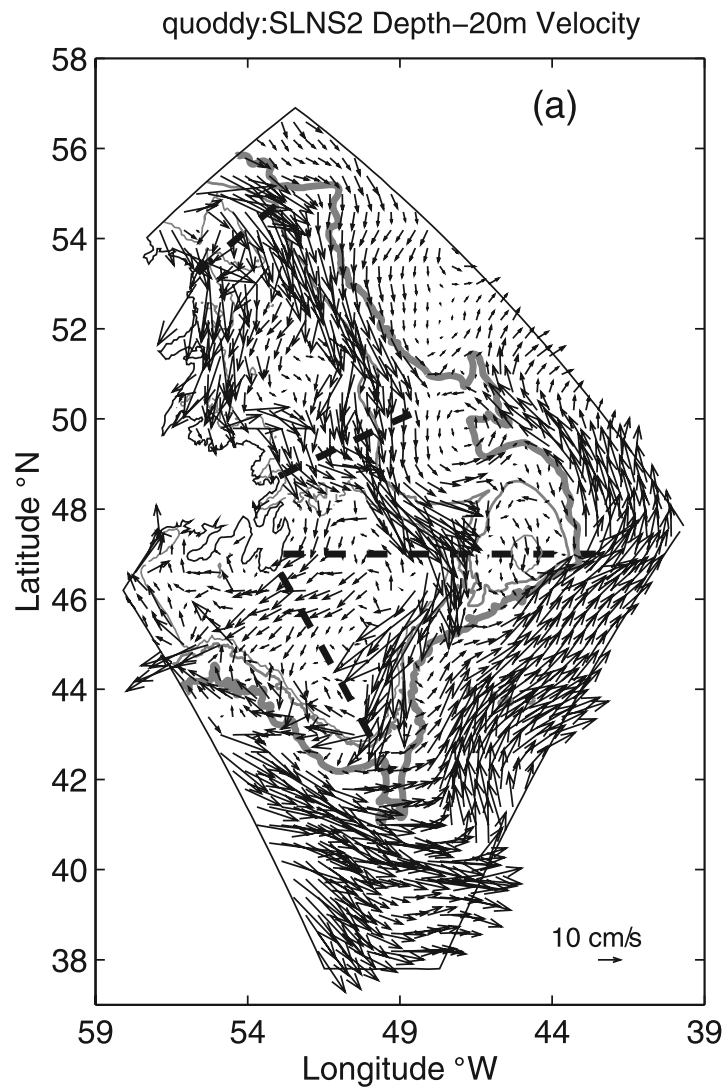

quoddy:SLNS2 Velocity at $20 \mathrm{~m}$ from bottom

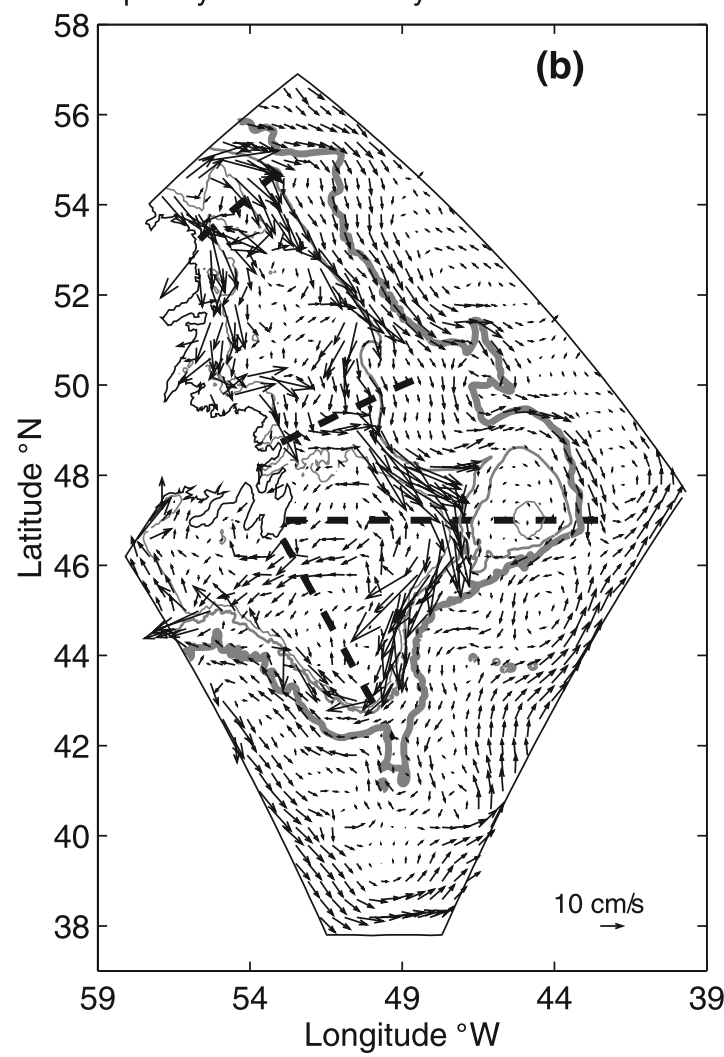

Figure 13. Model mean currents at the (a) $20 \mathrm{~m}$ below the surface and (b) $20 \mathrm{~m}$ above the bottom. The model fields have been subsampled for clarity of presentation. and $0.25 \mathrm{~Sv}$ for spring and summer, in approximate agreement with the model estimate of 0.49 and $0.3 \mathrm{~Sv}$.

\subsection{Validation Against Tide Gauge Data}

[33] Sea level data at St. John's tide gauge station (see Figure 1 for location) for 1990-1999 were obtained from the Marine Environmental Data Service of Fisheries and Oceans Canada. Monthly tide gauge data at St. John's were adjusted for inverse barometric effects using atmospheric pressure data observed at St. John's International Airport by Environmental Canada. Twelve long-term (1990-1999) monthly mean sea levels were calculated to represent seasonal sea level variations.

[34] Both tide gauge data and model results show significant seasonal sea level variations at St. John's (Figure 12). The annual sea level ranges are $0.21 \mathrm{~m}$ in the observations and about $0.19 \mathrm{~m}$ in the model solutions, high in fall/winter and low in spring/summer. The RMS sea level values are $7.1 \mathrm{~cm}$ for tide gauge observations and $6.8 \mathrm{~cm}$ for the model. The correlation coefficient is 0.98 (different from zero at the $99 \%$ confidence level). The RMS difference is $2.1 \mathrm{~cm}$. Therefore, the model sea level is in good agreement with tide gauge observations.

\section{Mean Circulation and Transport}

[35] The model mean currents at $20 \mathrm{~m}$ below the surface (Figure 13a) indicate dominant equatorward flows along the shelf break and upper continental slope (the shelf edge Labrador Current) and along the Labrador and Newfoundland coasts (the inshore Labrador Current) and a strong poleward flow near the 4000-m isobath (the Gulf Stream and its extension, the North Atlantic Current). In this paper we will focus on the features inshore of the 3000-m isobath. The model transport inshore of the $3000-\mathrm{m}$ isobath is $17 \mathrm{~Sv}$ at the SLS boundary. The cross-shelf and cross-slope exchanges are clearly evident. The near-bottom circulation is also substantial (Figure 13b), indicating the importance of the barotropic component (defined as the bottom current in this paper). Some bottom intensified topographic flow features are identified, e.g., the Flemish Cap eddy, the eddy over the southern tip $\left(50^{\circ} \mathrm{W}, 44^{\circ} \mathrm{N}\right)$ of the Grand Bank.

[36] The Seal Island transect is divided into three segments (see Table 3 and Figure 1 for definition) to distinguish different branches of the Labrador Current as indicated in previous studies [Lazier and Wright, 1993; Han, 2005]. The model transport in the inshore current is about $1.5 \mathrm{~Sv}$ (Figure 14a and Table 4), much larger than Lazier and Wright's [1993] observational estimate of $0.8 \mathrm{~Sv}$. The wind-driven component is calculated to be $0.7 \mathrm{~Sv}$ [Han, 2005]. The transport associated with the shelf edge current is about $7.5 \mathrm{~Sv}$ from the 200 to $1700-\mathrm{m}$ isobath, in which $1.5 \mathrm{~Sv}$ is wind-induced [Han, 2005]. The total transport estimated by Lazier and Wright [1993] using current meter observations and geostrophic methods is $6 \mathrm{~Sv}$. The model estimated transport is $5 \mathrm{~Sv}$ from 1700 to $3000-\mathrm{m}$ isobath, composed essentially of the wind-driven transport. The total mean transport inshore of the $3000-\mathrm{m}$ isobath is about $14 \mathrm{~Sv}$ at the Seal Island transect, indicating a substantial leakage offshore between the northern boundary and the transect.

[37] The shelf edge flow splits south of the Sea Island transect: one branch continues along the shelf edge and the 
Table 3. Depth Range of the Segments Along the Four Transects ${ }^{\mathrm{a}}$

\begin{tabular}{lcccc}
\hline \multicolumn{1}{c}{ Transect } & Inshore & $\begin{array}{c}\text { Shelf Edge/ } \\
\text { Upper Slope }\end{array}$ & $\begin{array}{c}\text { Lower } \\
\text { Slope }\end{array}$ & Slope \\
\hline Seal Island & Coast to 250 & $200-1700$ & $1700-3000$ & $200-3000$ \\
Bonavista & Coast to 300 & - & - & $300-2400$ \\
Flemish Cap & Coast to 100 & $130-1150$ & $1150-2400^{\mathrm{b}}$ & - \\
Southeast & Coast to 100 & - & - & $70-2400$
\end{tabular}

Grand Bank

${ }^{a}$ The depth range is given in $\mathrm{m}$. See Figure 1 for the geographical locations of the segments.

${ }^{\mathrm{b}}$ The offshore extent of this segment is located at about $45^{\circ} \mathrm{W}$ and $49^{\circ} \mathrm{N}$.

other partially steers onshore to join the inshore current and partially re-circulates around the Hamilton Bank (Figure 13). The above flow pattern contrasts with the mean surface circulation (Figure 10) due to the alongshelf surface Ekman flow. Most of the inshore branch continues along the northeastern Newfoundland coast. The flow across the Bonavista transect (Figure 13) is much broader, with no clear boundary between the inshore current and the shelf edge current. At about $49^{\circ} \mathrm{N}$, the depth-averaged flow pattern indicates that a significant portion of the inshore branch steers offshore to join the shelf edge current. A cyclonic eddy is evidently present at the 20-m depth over the Orphan Basin (Figure 13a), in between the equatorward shelf edge current and the poleward North Atlantic Current. The differences of flow patterns at the 20-m depth below the surface (Figure 13a) and at the 20-m above the bottom (Figure 13b) are indicative of substantial vertical current variations. The mean transport at the Bonavista transect is $0.8 \mathrm{~Sv}$ for the inshore current (depths $<300 \mathrm{~m}$ ) and $13 \mathrm{~Sv}$ for the slope current (depths $>300 \mathrm{~m}$ and $<2400 \mathrm{~m}$ ) (Figure $14 \mathrm{~b}$ and Table 4), in which 0.4 and $4 \mathrm{~Sv}$ are wind-driven, respectively [Han, 2005].

[38] The trifurcation of the slope current north of Flemish Pass is evident, with a strong stream through the Pass and a significant current toward the east along the northern flank of the Flemish Cap, and a weak flow onshore. At the Flemish Cap transect the transport of the nearshore current is $0.6 \mathrm{~Sv}$, and the transport through the Flemish Pass (from the $130-\mathrm{m}$ isobath on the Grand Bank side to the $1140-\mathrm{m}$ isobath on the Flemish Cap side) is $5.5 \mathrm{~Sv}$, in which about
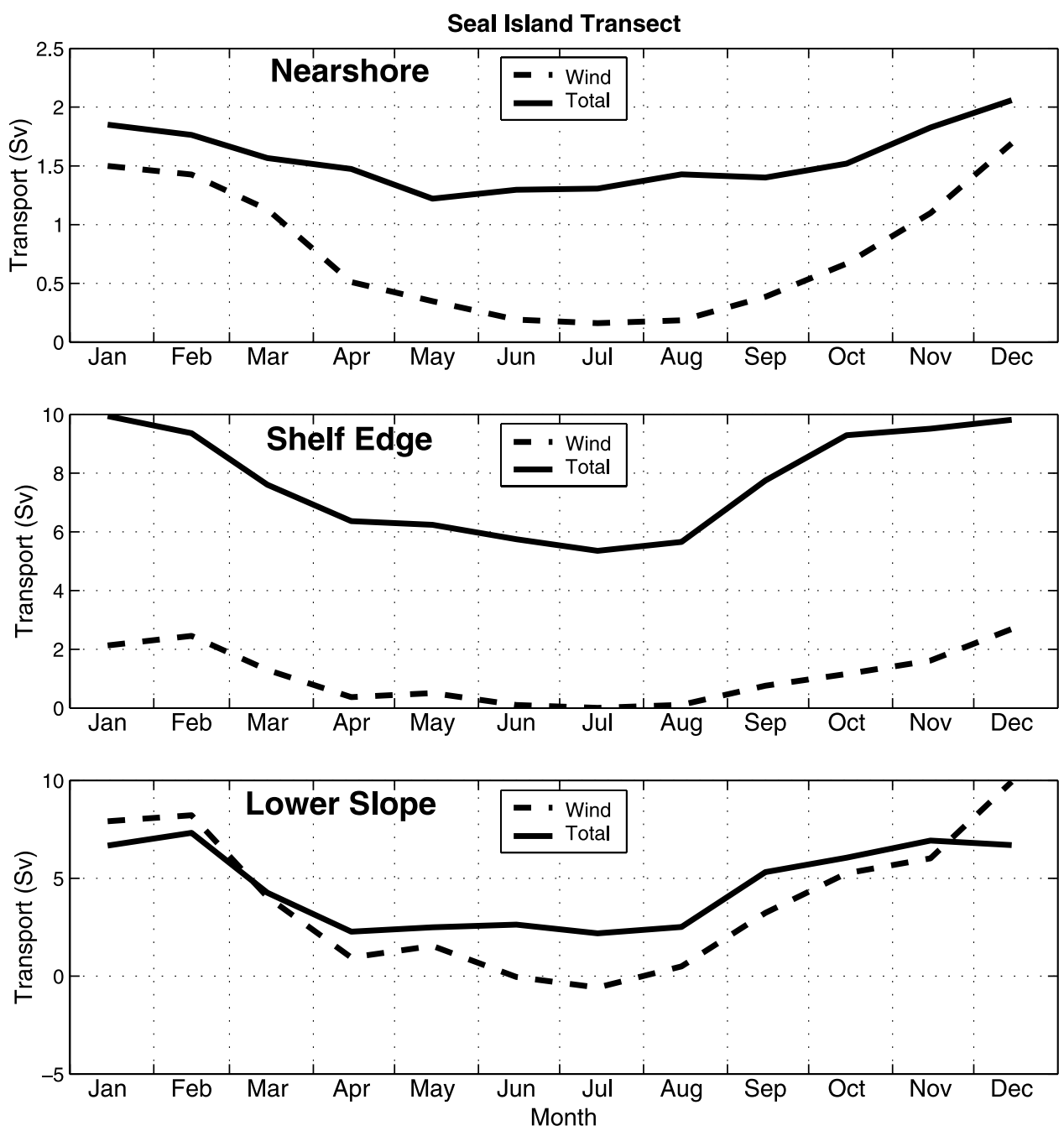

Figure 14. Monthly variations of volume transport through nearshore and slope segments at selected sections: the (a) Seal Island, (b) Bonavista, (c) Flemish Cap, and (d) Southeast Grand Bank transects. The wind-driven transport (both remote and regional forcing) from Han [2005] is also shown. See Table 3 and Figure 1 for the definition of the segments. 

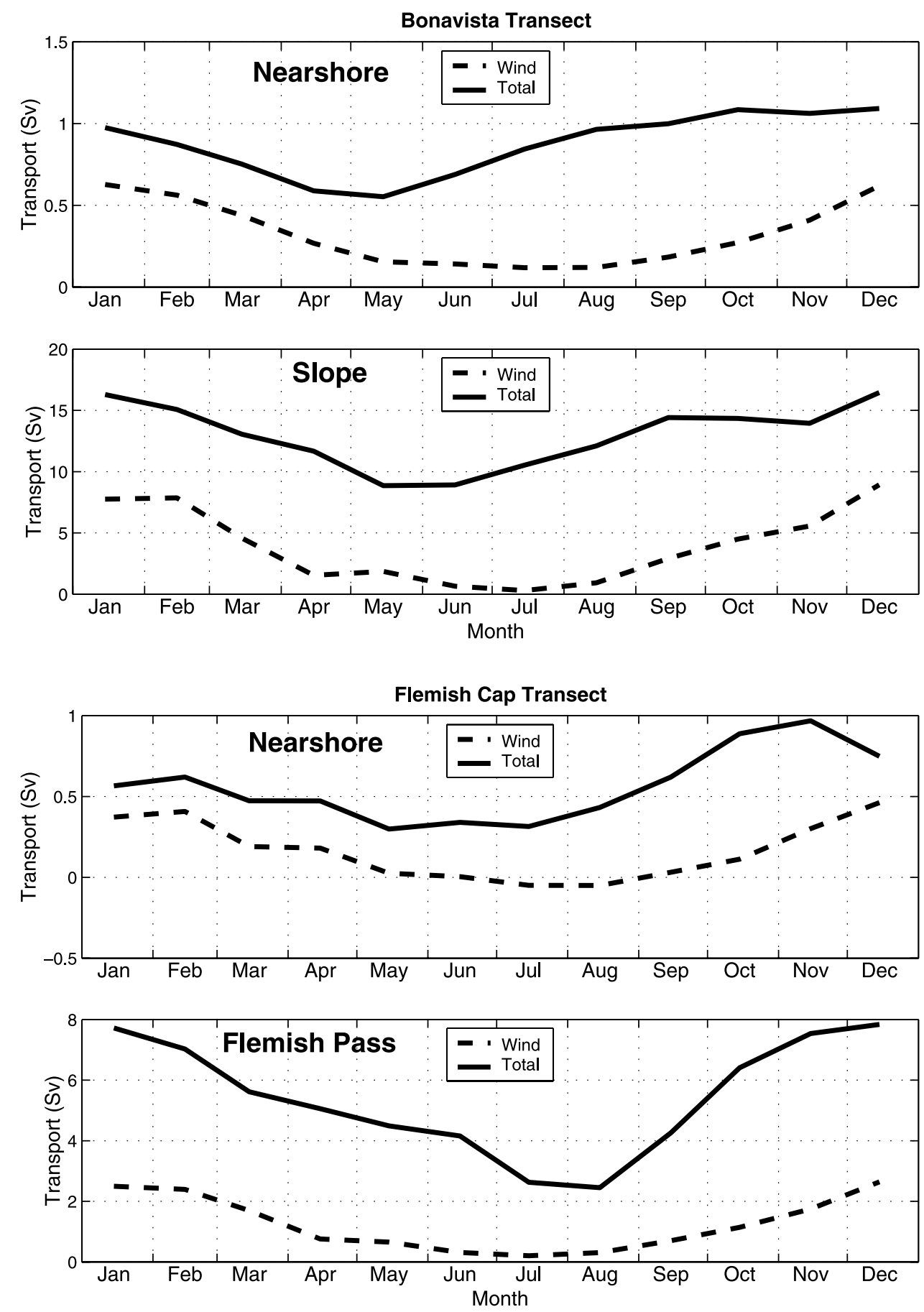

Figure 14. (continued)

one forth is wind-driven (Figure $14 \mathrm{c}$ and Table 4). The model transport through the Flemish Pass is consistent with the observational estimate of $5.8 \mathrm{~Sv}$. The eastward branch north of the Flemish Cap has a transport of $6.6 \mathrm{~Sv}$ (Table 4). The inshore branch, after passing through the Avalon Channel, bifurcates with one branch moving offshore along a deep channel and merging with the shelf edge current that has rounded the Tail of the Grand Bank. The wind driven transport through Avalon Channel is $0.2 \mathrm{~Sv}$ (inshore of the 90-m isobath) [Han, 2005], and the total model transport is $0.7 \mathrm{~Sv}$ in the present study. The total transport through the
Avalon Channel was estimated to be $0.39 \mathrm{~Sv}$ on the basis of current meter data [Greenberg and Petrie, 1988]. The slope current carries a transport of $3.5 \mathrm{~Sv}$ at the Southeast Grand Bank transect (from the 70-m isobath on the outer Grand Bank edge to the $2400-\mathrm{m}$ isobath), in which about $2 \mathrm{~Sv}$ is wind-driven (Figure 14d and Table 4). The geostrophic transport relative to $1000-\mathrm{m}$ depth was estimated to be 3.2 Sv [Petrie and Drinkwater, 1993]. Over the Grand Bank the currents are weak and diverse, generally directed southward/southwestward. The total Labrador Current transport was much smaller at the Southeast Grand Bank 

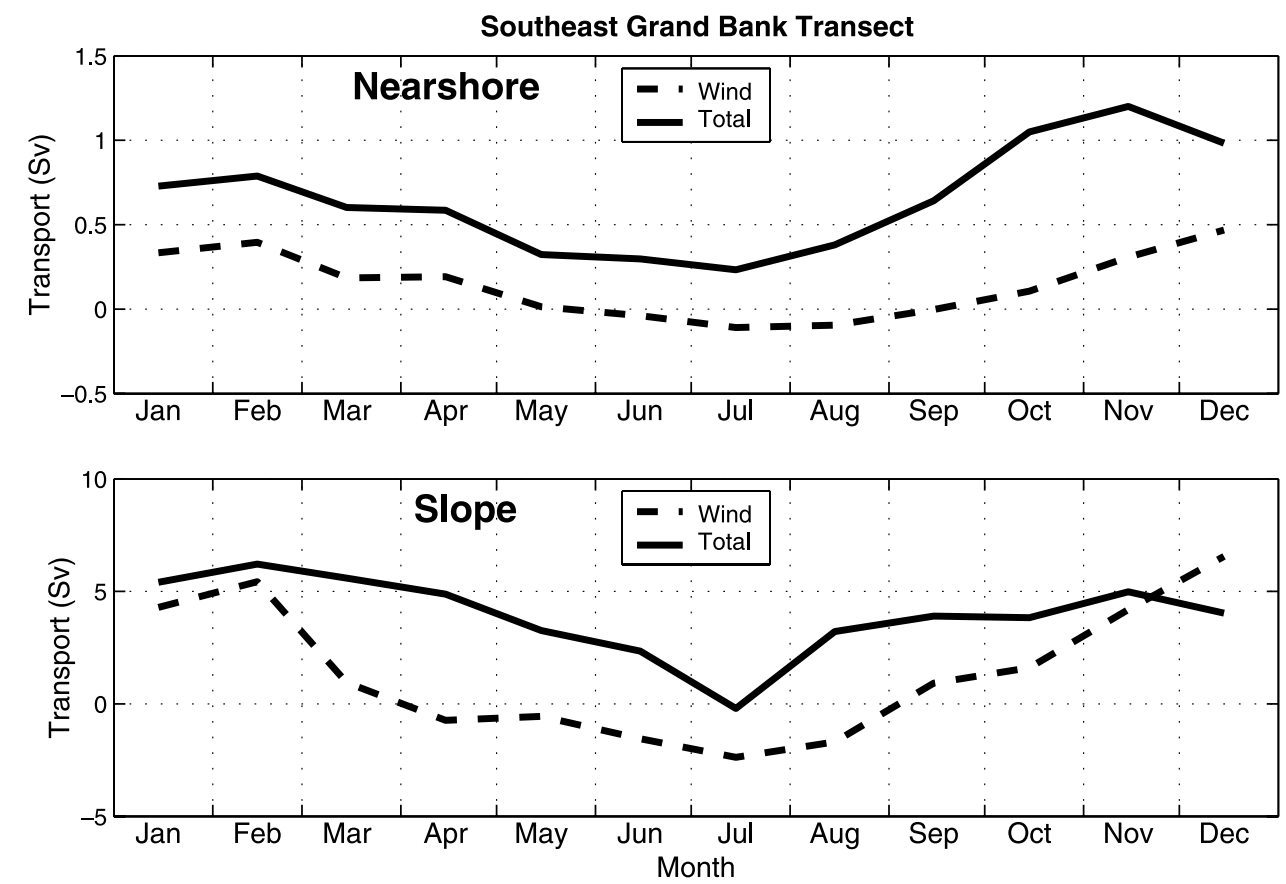

Figure 14. (continued)

transect than at the Flemish Cap transect, with the Labrador Current water being entrained into the northeastward North Atlantic Current.

[39] The inshore Labrador Current has a mean speed of $20-25 \mathrm{~cm} / \mathrm{s}$, extending to the sea bottom and within $50 \mathrm{~km}$ of the coast (Figure 15a). The shelf edge Labrador Current is centered along the $1000-\mathrm{m}$ isobath and has a magnitude of $25 \mathrm{~cm} / \mathrm{s}$ near the surface, with significant barotropic and baroclinic components. A strong onshore flow $(10-20 \mathrm{~cm} / \mathrm{s})$ is evident throughout the water column. Over the Hamilton Bank there is a bottom intensified anti-cyclonic eddy. The normal current at the Bonavista transect is more uniform along-transect, with a substantial offshore flow of $10 \mathrm{~cm} / \mathrm{s}$ (Figure 15b). The southward current through Flemish Pass is concentrated on the Grand Bank side (Figure 15c), with a surface current of $30-40 \mathrm{~cm} / \mathrm{s}$ and a bottom current of $20 \mathrm{~cm} / \mathrm{s}$ at the $200-\mathrm{m}$ isobath. There is a narrow coastal jet with a speed of $5-10 \mathrm{~cm} / \mathrm{s}$ through Avalon Channel (Figure 15d).

[40] The present model solutions indicate that the densitydriven component is predominant in the shelf edge Labrador Current at the Seal Island transect and through the Flemish Pass. The wind-forced component is relatively more significant in the inshore Labrador Current transport, responsible for about half of the total transport at both the Seal Island and Flemish Cap transects.

\section{Seasonal Current and Transport Variations}

[41] The inflow inshore of the 3000-misobath at the northern boundary has a transport range of about $15 \mathrm{~Sv}$. The seasonal transport variability is significantly reduced from the northern boundary to the Seal Island transect. The transport at the Seal Island transect has a seasonal cycle of $0.8 \mathrm{~Sv}$ (Table 5) associated with the inshore current, largest in December (2 Sv) and smallest in May (1.2 Sv)
(Figure 14a). The seasonal range of the total transport is much smaller than that of the wind-driven component because the density-driven component is larger in spring/ summer than in winter/fall for the inshore current. The total shelf edge current has a seasonal range of $4.5 \mathrm{~Sv}$ from the 200 to $1700-\mathrm{m}$ isobath (Table 5), largest in DecemberJanuary (about $10 \mathrm{~Sv}$ ) and smallest in June-August (about $6 \mathrm{~Sv})$. The wind-driven transport has a seasonal cycle of $2.5 \mathrm{~Sv}$. Therefore, the density and wind-forcing seems to play comparable roles in the seasonal variability of the Labrador Current.

[42] At the Bonavista transect, the seasonal range is 1.3 and $8.5 \mathrm{~Sv}$ for the inshore and for the slope current, respectively (Figure 14b and Table 5). Both currents are strongest in December and weakest in May. The seasonal cycle of the slope current at the Bonavista transect which ends at the $2400-\mathrm{m}$ isobath is comparable to that (from the sum of the shelf edge and lower-slope branches) at the Seal Island transect off Labrador.

Table 4. Mean Volume Transport Through the Segments Along the Four Transects ${ }^{\mathrm{a}}$

\begin{tabular}{lcccc}
\hline \multicolumn{1}{c}{ Transect } & Inshore & $\begin{array}{c}\text { Shelf Edge/ } \\
\text { Upper Slope }\end{array}$ & $\begin{array}{c}\text { Lower } \\
\text { Slope }\end{array}$ & Slope \\
\hline Seal Island & 1.5 & $7.5(6)$ & 5 & 12.5 \\
Bonavista & 0.8 & - & - & 12.9 \\
Flemish Cap & $0.6(0.4)$ & 5.5 & $6.6^{\mathrm{b}}$ & - \\
Southeast & 0.6 & - & - & $3.6(3.2)$ \\
Grand Bank & & & &
\end{tabular}

${ }^{\mathrm{a}}$ The mean volume transport is given in Sv. See Figure 1 and Table 3 for the segment location information. Observational estimates from Lazier and Wright [1993], Greenberg and Petrie [1988], and Petrie and Drinkwater [1993] are shown in parentheses.

${ }^{\mathrm{b}}$ The mean volume transport of the eastward flow north of the Flemish Cap. 

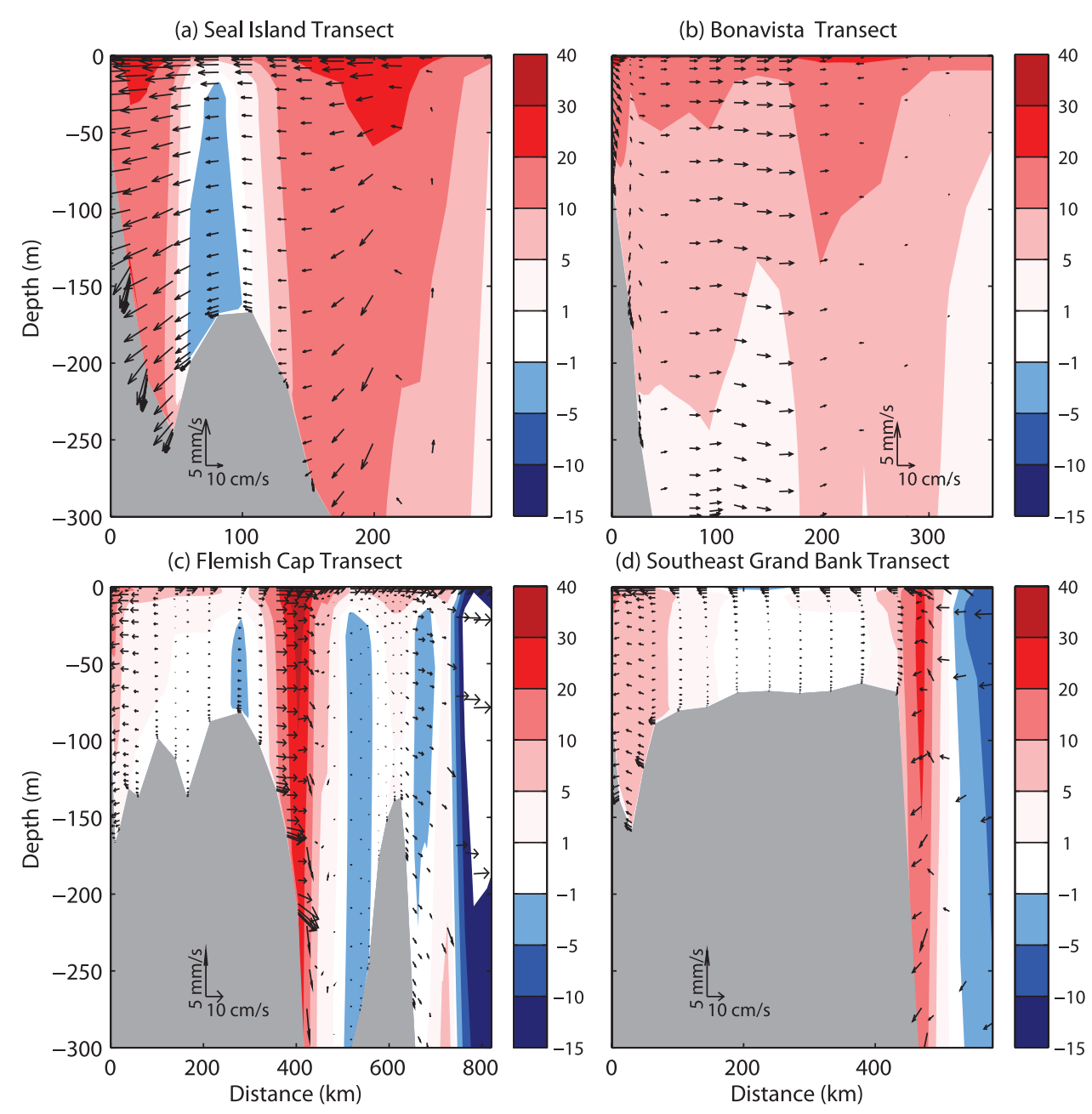

Figure 15. Mean velocity distribution on the (a) Seal Island, (b) Bonavista, (c) Flemish Cap, and (d) Southeast Grand Bank transects from the model solutions. The color bands are for the normal currents $(\mathrm{cm} / \mathrm{s})$, positive southward. The distance is measured from the coast.

[43] The model solutions indicate that the transport through the Flemish Pass has a seasonal variation of 5.2 Sv (Figure 14c and Table 5), largest in DecemberJanuary $(7.8 \mathrm{~Sv})$ and smallest in July-August $(2.6 \mathrm{~Sv})$. The significantly reduced seasonal range through Flemish Pass is due to the splitting of the Labrador Current north of the Pass (The eastward branch has an October-July range of 5.5 Sv (Table 5)). Half of the seasonal range of the Flemish Pass flow can be attributed to wind effect [Han, 2005]. The nearshore current has a similar phase variation, with a transport range of $0.6 \mathrm{~Sv}$ (Table 5). At the Southeast Grand Bank transect the inshore transport through the Avalon Channel has a seasonal cycle of $0.5 \mathrm{~Sv}$ (Figure $14 \mathrm{~d}$ and Table 5). The seasonal range is about $5 \mathrm{~Sv}$ for the equatorward slope current, which is largest in February and nearly zero in July. Similar to the mean transport, the seasonal range of the equatorward flow is significantly reduced from the Flemish Cap transect to the Southeast Grand Bank transect (Table 5).

[44] The present model results at the 20-m depth clearly show significant seasonal circulation variations off Newfoundland and Labrador, with more intense currents (especially near the shelf edge) in November than in July
(Figure 16a). The topographic-scale features, such as a cyclonic eddy over the Orphan Basin and an anticyclonic partial gyre over the Flemish Cap, are also intensified in November. The near bottom current (not shown) also has substantial seasonal variation, especially in the shelf edge Labrador Current.

Table 5. Seasonal Range of Volume Transport Through the Segments Along the Four Transects ${ }^{\mathrm{a}}$

\begin{tabular}{lcccc}
\hline \multicolumn{1}{c}{ Transect } & Inshore & $\begin{array}{c}\text { Shelf Edge/ } \\
\text { Upper Slope }\end{array}$ & $\begin{array}{c}\text { Lower } \\
\text { Slope }\end{array}$ & Slope \\
\hline Seal Island & 0.8 & 4.5 & 5 & 9.5 \\
Bonavista & 1.3 & - & - & 8.5 \\
Flemish Cap & 0.6 & 5.2 & $5.5^{\mathrm{b}}$ & - \\
Southeast & 0.5 & - & - & 5
\end{tabular}

Grand Bank

${ }^{\mathrm{a}}$ The seasonal range of volume transport is given in Sv. The seasonal transport range is defined as the difference between the transport maximum and the transport minimum in 12 months (also refer to Figure 14). See Figure 1 and Table 3 for the segment location information.

${ }^{\mathrm{b}}$ The volume transport of the eastward flow north of the Flemish Cap. 

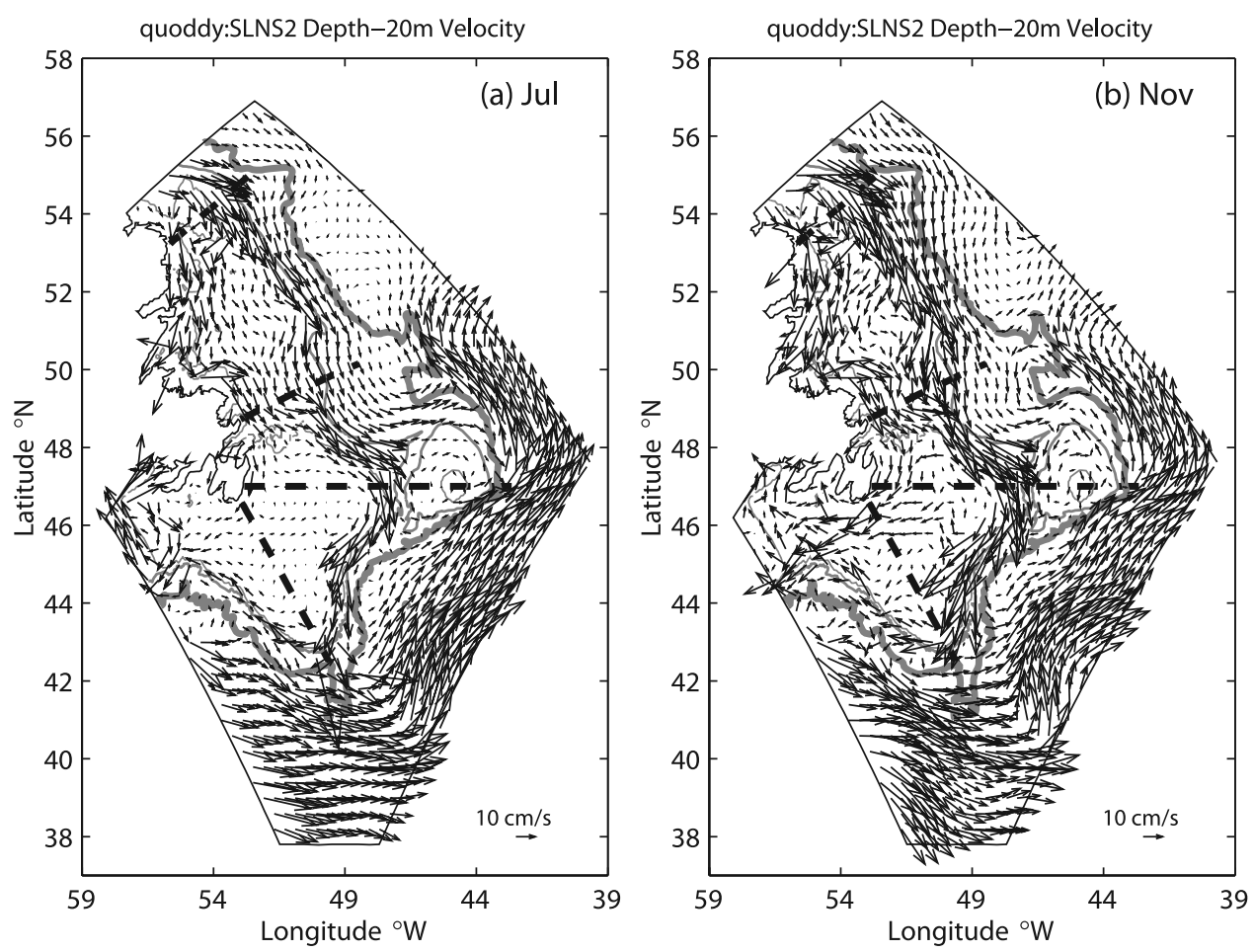

Figure 16. Model circulation fields at the 20-m depth for (a) July and (b) November, representing summer and fall, respectively. The model fields have been subsampled for clarity of presentation. The 200,1000 , and $3000-\mathrm{m}$ isobaths are depicted as the gray lines.

[45] At the Seal Island transect (Figure 17), the inshore Labrador Current is $20-30 \mathrm{~cm} / \mathrm{s}$ in November and extended to the bottom $(100-150 \mathrm{~m}$ depth), in contrast to the current speed of $10-20 \mathrm{~cm} / \mathrm{s}$ in July. The shelf edge Labrador Current in November is broad and strong, with a normal current of $30 \mathrm{~cm} / \mathrm{s}$ at the surface and a near bottom speed of above $10 \mathrm{~cm} / \mathrm{s}$ at the $1000-\mathrm{m}$ isobath. The onshore flow is also much stronger in November than in July. The Labrador Current through the Flemish Pass is also strong in November, with a speed of $40 \mathrm{~cm} / \mathrm{s}$ at the surface, while the current is $20-30 \mathrm{~cm} / \mathrm{s}$ in July. The inshore current has a speed of $10-$ $15 \mathrm{~cm} / \mathrm{s}$ in November and $5 \mathrm{~cm} / \mathrm{s}$ in July.

[46] Overall both buoyancy and wind-forcings play a comparable role in the magnitude of the seasonal transport variability of both the inshore and shelf edge Labrador Current, but with significantly different phase evolutions. The density driven component is largest in late summer/ early fall for the inshore current. For the wind driven component, both the inshore and offshore Labrador Currents are largest in late fall/early winter. The shelf edge Labrador Current peaks in fall at the Seal Island transect (Figure 14a (middle)) and Flemish Cap transect (Figure 14c (bottom)); while the slope current peaks at the Seal Island (Figure 14a (middle) and (bottom)) and Bonavista (Figure 14b (bottom)) transects in December-February and at the Southeast Grand Bank transect (Figure 14d (bottom)) in February.

\section{Discussions}

\subsection{Total and Tidal Dissipation}

[47] The vertically integrated dissipation rate (Figure 18a) indicates that the total dissipation associated with the tidal and monthly mean flows is larger along the Labrador coast, in the Strait of Belle Isle and over the shelf edge in November. Typical values are in the range of $0.01 \mathrm{~W} / \mathrm{m}^{2}$. Over most of the shelf areas, the value varies from 0.001 to $0.01 \mathrm{~W} / \mathrm{m}^{2}$. The model dissipation associated with the $M_{2}$ tidal forcing is generally below $0.0001 \mathrm{~W} / \mathrm{m}^{2}$, except for the Southeast Shoal near the Tail of Grand Bank and the Strait of Belle Isle where the $M_{2}$ tidal current are relatively strong (Figure 18b). Therefore, most of the dissipation can be attributed to the monthly mean flow. In July (Figure 18c) the total dissipation is weaker overall than that in November, resulting from weaker mean currents and stronger vertical stratification over the shelf and slope. However, tidal contribution is more significant near the shelf edge of the Southeast Shoal (Figure 18d), which may suggest a generation of baroclinic tides. Nevertheless, the use of the temperature and salinity nudging method at the tidal timescale is inappropriate for examining the baroclinic tides and associated mixing effects and the topic is beyond the scope of the present study.

[48] Inclusion of the $M_{2}$ tide does not change the modeldata comparison statistics for the monthly mean flows, which indicates that the tidally rectified residual current is generally negligible over the Newfoundland and Labrador Shelf and slope.

\subsection{Effects of the Large-Scale Wind-Forcing}

[49] The relative role of the large-scale to regional windforcing in the wind-driven barotropic Labrador Current was revealed by Han [2005]. The importance of the large-scale remote wind-forcing can be further elucidated in the present study. The solutions under the remote wind-forcing were obtained from the model forced on the open boundary by 
(a) Seal Island Transect (Jul)

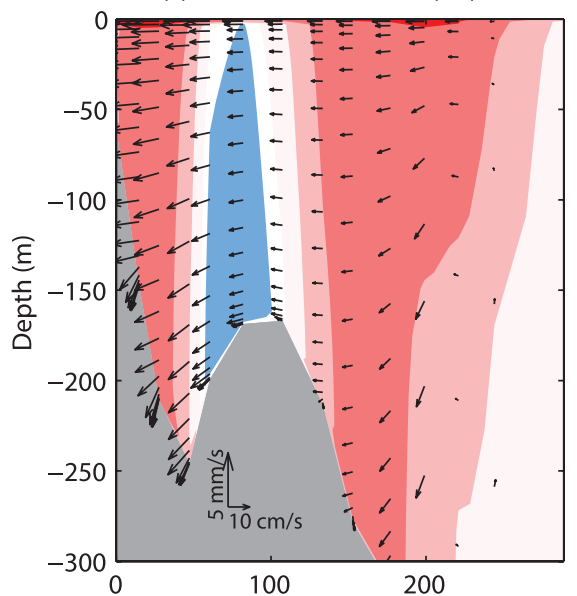

(c) Flemish Cap Transect (Jul)
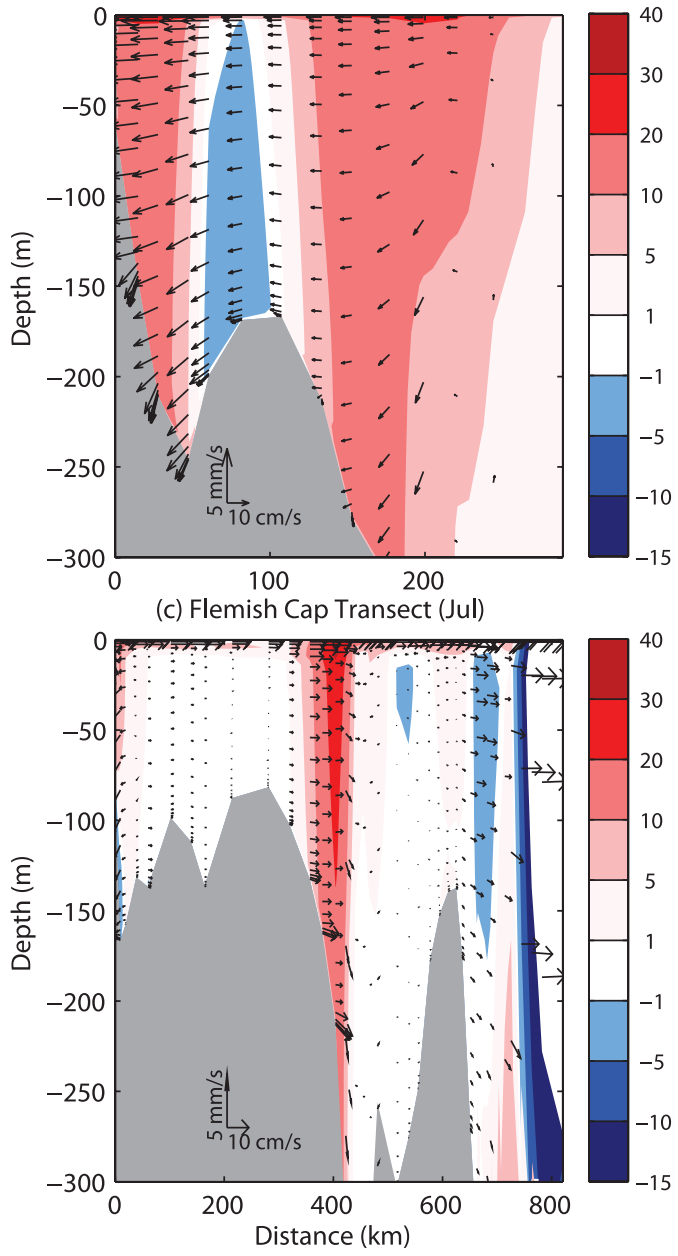

(b) Seal Island Transect (Nov)

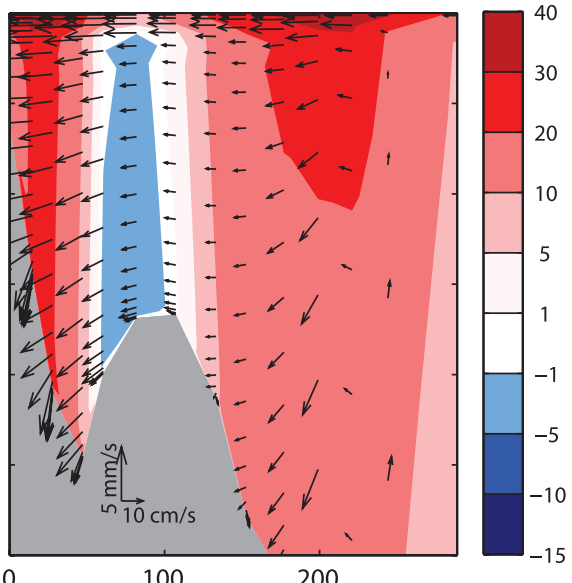

(d) Flemish Cap Transect (Nov)

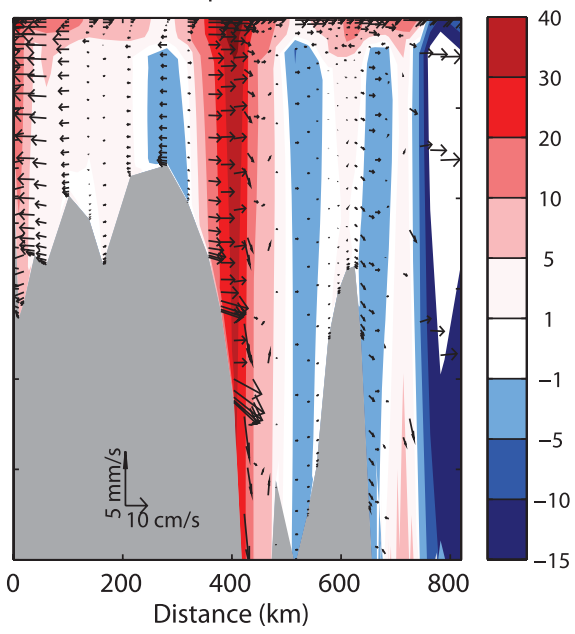

Figure 17. Velocity on the (a and b) Seal Island and ( $c$ and d) Flemish Cap transects in July (Figures 17a and $17 \mathrm{c}$ ) and November (Figures $17 \mathrm{~b}$ and $17 \mathrm{~d}$ ) from the model solutions. The color bands are for the normal currents $(\mathrm{cm} / \mathrm{s})$, positive southward. The distance is measured from the coast.

the sea level derived from the wind-driven North Atlantic model. In general, the large-scale forcing increases the mean transport of the Labrador Current and enhances its seasonal cycle. The effect is most significant over the Labrador Slope and gradually reduced downstream and toward the coast.

[50] For the mean component of the shelf edge Labrador Current, the transport associated with the remote windforcing is $1.5 \mathrm{~Sv}$ at the Seal Island transect, substantial in comparison with the total model transport of $7.5 \mathrm{~Sv}$. Through the Flemish Pass, the transport due to the remote wind effect is $1 \mathrm{~Sv}$, about $1 / 6$ of the total transport.

[51] On the seasonal scale, the effect of the large-scale wind-forcing is more prominent. The seasonal range of the shelf edge current associated with the remote wind-forcing is $2.5 \mathrm{~Sv}$ and $1.7 \mathrm{~Sv}$ at Seal Island transect and through the Flemish Pass, accounting for nearly half and one third of the seasonal variation, respectively.

[52] Exclusion of the large-scale wind-forcing significantly degrades the model-data comparison statistics for fall/winter months. For example, the spatially averaged speed from the model solutions in November decreases to $8.1 \mathrm{~cm}$ for the selected observational sites (Table 6), significantly lower than the observational average of $12.0 \mathrm{~cm} / \mathrm{s}$. The VDR value increases from 0.35 to 0.48 . In contrast, the effect is negligible in July (Table 6) and for the other summer months.

\section{Concluding Remarks}

[53] We have investigated seasonal circulation variability for the Newfoundland and Labrador Shelf and Slope by the prognostic refinement of the diagnostic circulation fields. The refinement was carried out within a fully nonlinear circulation model with an advanced turbulence scheme under joint forcing of wind, density and tides. The results have been evaluated against and discussed together with in situ observations, for major current features, seasonal variations, and underlying dynamics.

[54] The refinement was carried out by restoring the model temperature and salinity toward their initial values (for the first $M_{2}$ cycle) or toward evolving immediately preceding $M_{2}$ cycle mean values (for the second and subsequent $M_{2}$ cycle). The approach is conceptually and dynamically more realistic than the pure diagnostic one. It proves to be effective in preventing unrealistic model drift and suppressing potentially catastrophic numeric instability 

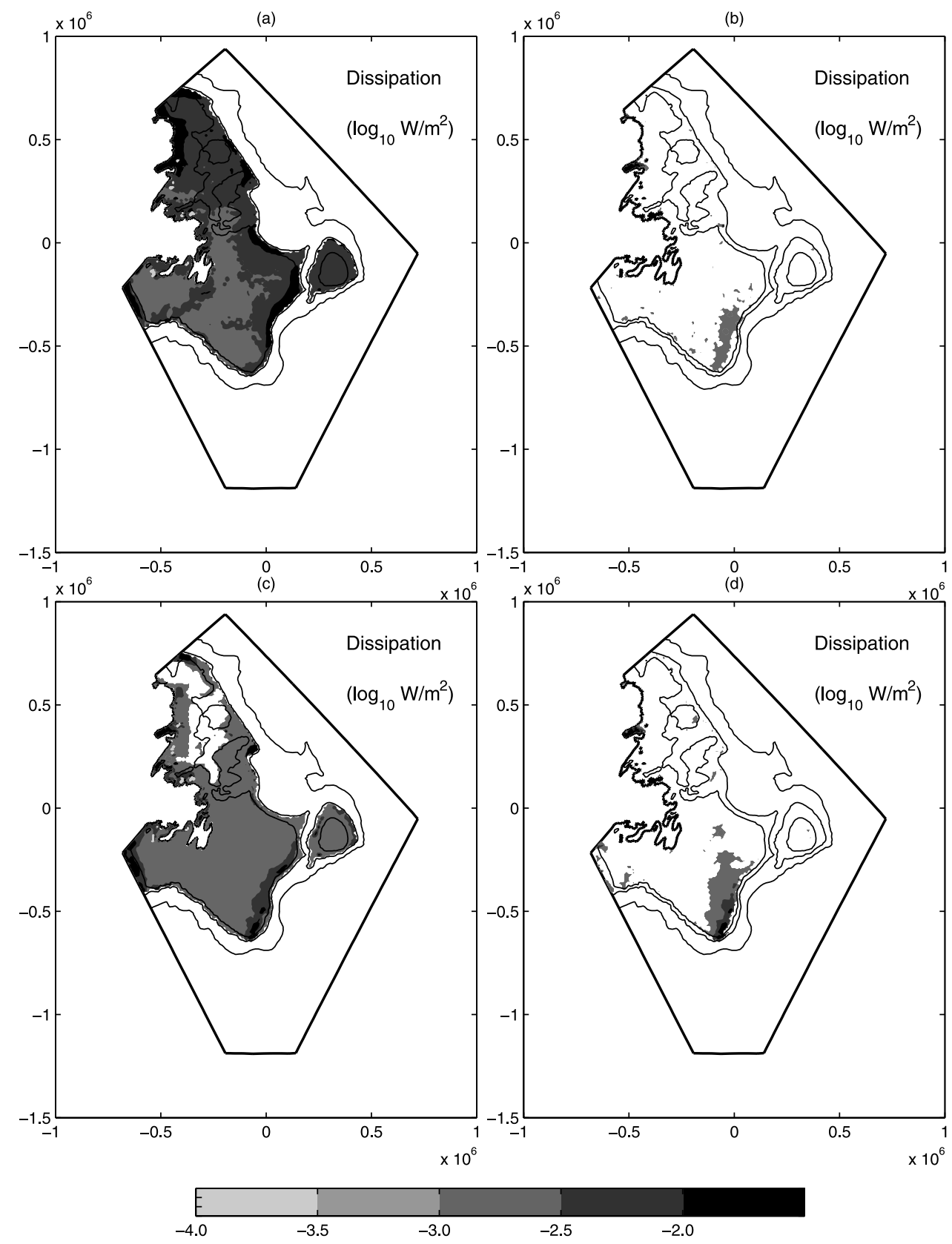

Figure 18. Depth-integrated dissipation rate inshore of the 1000-m isobath. (a) Total dissipation in November, (b) tidal dissipation in November, (c) total dissipation in July, and (d) tidal dissipation in July. The 300, 1000, and 3000-m isobaths are also depicted.

and in allowing local dynamical adjustment within the tidal timescale.

[55] The model circulation features are generally consistent with previous model results, with significant enhance- ment in resolving the inshore and shelf edge Labrador Current. Detailed comparison of the model circulation with moored current meter data, vessel mounted ADCP data, and surface current estimates from satellite-tracked drifters in-

Table 6. Same as Table 2 but the Model Results Do Not Include the Large-Scale Wind-Forcing in the North Atlantic

\begin{tabular}{|c|c|c|c|c|c|c|c|c|}
\hline \multirow[b]{2}{*}{ Month } & \multirow{2}{*}{$\begin{array}{c}\text { Number of } \\
\text { Observations }\end{array}$} & \multicolumn{2}{|c|}{ Average Speed $(\mathrm{cm} / \mathrm{s})$} & \multirow[b]{2}{*}{ SDR } & \multirow[b]{2}{*}{ VDR } & \multirow[b]{2}{*}{$R$} & \multicolumn{2}{|c|}{ Velocity Deviations } \\
\hline & & Observed & Model & & & & $\operatorname{VVD}(\mathrm{cm} / \mathrm{s})$ & $\mathrm{DA}\left({ }^{\circ}\right)$ \\
\hline July & 169 & $8.3 \pm 6.3$ & $6.9 \pm 5.7$ & 0.34 & 0.54 & 0.68 & $6.1 \pm 4.7$ & $47 \pm 64$ \\
\hline November & 93 & $12.0 \pm 8.7$ & $8.1 \pm 6.3$ & 0.35 & 0.48 & 0.7 & $7.9 \pm 6.5$ & $44 \pm 56$ \\
\hline
\end{tabular}


dicate approximate agreement with observations for the major currents. The model sea level agrees well with tide gauge observations at St. John's.

[56] The present model results indicate significant seasonal and spatial variations in the regional circulation. The region is dominated by the equatorward flowing Labrador Current along the shelf edge and along the Labrador and Newfoundland coasts. The Labrador Current is strong in the fall/winter and weak in the spring/summer. The annualmean transport of the shelf edge Labrador Current is $7.5 \mathrm{~Sv}$ at Hamilton Bank and 5.5 Sv through the Flemish Pass. The seasonal ranges are 4.5 and $5.2 \mathrm{~Sv}$ at the two sections.

[57] The seasonal-mean circulation solutions are discussed in terms of relative importance of wind to density forcing for the Labrador Currents. For the mean circulation, the model solutions indicate the shelf edge Labrador Current is dominated by the density-driven component at the Seal Island transect and through the Flemish Pass. The windforced component is comparable in the inshore Labrador Current transport. On the seasonal scale, both buoyancyand wind-driven components contribute comparably to the magnitude of the transport variability of both the inshore and shelf edge Labrador Current, but differently to the phase evolution. The density-driven inshore component is largest in late summer/early fall. Both the wind-driven inshore and offshore Labrador Currents are strongest in late fall/early winter. The shelf edge Labrador Current peaks in fall at the Seal Island and Flemish Cap transects; while the slope current peaks at the Seal Island and Bonavista transects in December-February and at the Southeast Grand Bank transect in February.

[58] Acknowledgments. We wish to thank D. Senciall for providing the ADCP data and J. Sheng for providing the temperature and salinity climatology. Comments and suggestions received from the two anonymous reviewers and Robert Weisberg helped significantly improve the manuscript. This work has been funded by the Offshore Environmental Factors program of the (Canadian) Program for Energy, Research, and Development; the Mathematics of Information Technology and Complex Systems; and the Aquatic Invasive Species Program of the Fisheries and Oceans Canada.

\section{References}

Blumberg, A. F., B. Galperin, and D. J. O'Connor (1992), Modeling vertical structure of open-channel flows, J. Hydraul. Eng., 118, 1119-1134, doi:10.1061/(ASCE)0733-9429(1992)118:8(1119).

Foreman, M. G. G., R. E. Thomson, and C. L. Smith (2000), Seasonal current simulations for the western continental margin off Vancouver Island, J. Geophys. Res., 105(C8), 19,665-19,668, doi:10.1029/ 2000JC900070.

Fratantoni, P. S., and R. S. Pickart (2007), The western North Atlantic shelfbreak current system in summer, J. Phys. Oceanogr., 37, 2509.

Geshelin, Y., J. Sheng, and R. J. Greatbatch (1999), Monthly mean climatologies of temperature and salinity in the western North Atlantic, Can. Tech. Rep. Hydrogr. Ocean Sci. 153, 62 pp., Ocean Sci. Div. of Fish. and Ocean Can., Dartmouth, N. S., Canada.

Greenberg, D. A., and B. D. Petrie (1988), The mean barotropic circulation on the Newfoundland Shelf and Slope, J. Geophys. Res., 93, 15,54115,550, doi:10.1029/JC093iC12p15541.

Gregory, D. N., and C. Bussard (1996), Current statistics for the Scotian Shelf and Slope, Can. Data Rep. Hydrogr. Ocean Sci. 144, 167 pp., Ocean Sci. Div. of Fish. and Ocean Can., Dartmouth, N. S., Canada.
Han, G. (2000), Three-dimensional modeling of tidal currents and mixing quantities over the Newfoundland Shelf, J. Geophys. Res., 105, 11,40711,422, doi:10.1029/2000JC900033.

Han, G. (2005), Wind-driven barotropic circulation off Newfoundland and Labrador, Cont. Shelf Res., 25, 2084-2106, doi:10.1016/ j.csr.2005.04.015.

Han, G., and J. W. Loder (2003), Three-dimensional modeling of seasonalmean and tidal currents over the eastern Scotian Shelf, J. Geophys. Res., 108(C5), 3136, doi:10.1029/2002JC001463.

Han, G., and C. L. Tang (1999), Velocity and transport of the Labrador Current determined from altimetric, hydrographic, and wind data, J. Geophys. Res., 104, 18,047-18,057, doi:10.1029/1999JC900145.

Han, G., and C. L. Tang (2001), Interannual variation of volume transport in the western Labrador Sea based on TOPEX/Poseidon and WOCE data, J. Phys. Oceanogr., 31, 199-211, doi:10.1175/15200485(2001)031<0199:IVOVTI>2.0.CO;2.

Han, G., M. Ikeda, and P. C. Smith (1996), Oceanic tides on the Newfoundland and Scotian shelves from TOPEX/POSEIDON altimetry, Atmos. Ocean, 34(4), 589-604.

Han, G., C. G. Hannah, J. W. Loder, and P. C. Smith (1997), Seasonal variation of the three-dimensional mean circulation over the Scotian Shelf, J. Geophys. Res., 102(C1), 1011-1025, doi:10.1029/96JC03285.

Han, G., J. W. Loder, and P. C. Smith (1999), Seasonal-mean hydrography and circulation in the Gulf of St. Lawrence and eastern Scotian and southern Newfoundland Shelves, J. Phys. Oceanogr., 29(6), 12791301, doi:10.1175/1520-0485(1999)029<1279:SMHACI>2.0.CO;2.

Hannah, C. G., D. A. Greenberg, J. W. Loder, and Z. Xu (1995), Seasonal baroclinic circulation in the Scotia-Maine and Grand Banks regions, Can. Tech. Rep. Hydrogr. Ocean Sci. 169, pp. 81-85, Ocean Sci. Div. of Fish. and Ocean Can., Dartmouth, N. S., Canada.

Lazier, J. R. N., and D. G. Wright (1993), Annual velocity variations in the Labrador Current, J. Phys. Oceanogr., 23, 659-678, doi:10.1175/15200485(1993)023<0659:AVVITL>2.0.CO;2.

Loder, J. W., G. Han, C. G. Hannah, D. A. Greenberg, and P. C. Smith (1997), Hydrography and baroclinic circulation in the Scotian Shelf region: Winter versus summer, Can. J. Fish. Aquat. Sci., 54, 40-56, doi:10.1139/cjfas-54-S1-40.

Loder, J. W., B. D. Petrie, and G. Gawarkiewicz (1998), The coastal ocean off northeastern North America: A large-scale view, in The Global Coastal Ocean: Regional Studies and Synthesis, vol. 11, edited by K. H. Brink and A. R. Robinson, chap. 5, pp. 105-133, John Wiley, Hoboken, N. J.

Lynch, D. R., J. T. C. Ip, C. E. Naimie, and F. E. Werner (1996), Comprehensive coastal circulation model with application to the Gulf of Maine, Cont. Shelf Res., 16, 875-906, doi:10.1016/0278-4343(95)00028-3.

Mellor, G. L., and T. Yamada (1982), Development of a turbulence closure model for geophysical fluid problems, Rev. Geophys., 20, 851-875, doi:10.1029/RG020i004p00851.

Naimie, C. E., and D. R. Lynch (1993), FUNDY5 Users' Manual, 40 pp., Numer. Methods Lab., Hanover, N. H.

Petrie, B., and C. Anderson (1983), Circulation on the Newfoundland continental shelf, Atmos. Ocean, 21, 207-226.

Petrie, B. D., and K. Drinkwater (1993), Temperature and salinity variability on the Scotian Shelf and in the Gulf of Maine 1945-1990, J. Geophys. Res., 98, 20,079-20,089, doi:10.1029/93JC02191.

Senciall, D., N. Chen, E. Cobourne, G. Han, and J. Loder (2006), ADCP currents along the Flemish Cap Transect, Fish. and Oceans Can., Mont-Joli, Que., Canada.

Sheng, J., and K. Thompson (1996), Surface circulation on the Newfoundland Shelf and Grand Banks: The roles of local density gradients and remote forcing, Atmos. Ocean, 43, 257-284.

Tang, C. L., Q. Gui, and I. K. Peterson (1996), Modeling the mean circulation of the Labrador Sea and the adjacent shelves, J. Phys. Oceanogr., 26, $1989-2010$.

Therriault, J.-C., et al. (1998), Proposal for a northwest Atlantic zonal monitoring program, Can Tech. Rep. Hydrogr. Ocean Sci. 194, 57 pp., Ocean Sci. Div. of Fish. and Ocean Can., Dartmouth, N. S., Canada.

N. Chen, G. Han, J. Helbig, and Z. Wang, Biological and Physical Oceanography Section, Fisheries and Oceans Canada, Northwest Atlantic Fisheries Centre, 80 East White Hills Road, St. John's, NL A1C 5X1, Canada. (guoqi.han@dfo-mpo.gc.ca)

B. de Young and Z. Lu, Department of Physics and Physical Oceanography, Memorial University of Newfoundland, P.O. Box 4200, St. John's, NL A1C 5S7, Canada. 